\title{
Fernando el Católico ante la Muerte: el atentado de Barcelona y sus relatores
}

Ferdinand the Catholic faces death:
the Barcelona assault and its narrators

\section{Teresa JiMÉNEZ CALVENTE}

Universidad de Alcalá, Dpto. de Filología, Comunicación y Documentación

Facultad de Filosofía y Letras

teresa.jimenez@uah.es

Abstract: On December $7^{\text {th }} 1492$, during a visit to Barcelona, King Ferdinand was severely injured by a local peasant. His life was not endangered and his wounds healed soon, which were undeniable evidences of God's intervention. In many senses, providentialism gives a convincing answer to the development of the facts, its sequence and happy ending. Furthermore, it reinforces the Royal image by means of both Messianic and Scatological elements. This research concentrates on the writings related to this assault and includes the edition of an important letter.

Keywords: Barcelona assault; Ferdinand the Catholic King; Isabella the Catholic Queen; Royal propaganda; Carlo and Marcelino Verardi; Pedro Mártir de Anglería; Lucio Marineo Sículo; Andrés Bernáldez; Pere Miquel Carbonell; Hernando de Talavera; Fernán Álvarez de Toledo; Alonso Ortiz; MSS 7076 BNE.
Resumen: El 7 de diciembre de 1492, en Barcelona, el rey Fernando el Católico sufrió un atentado que estuvo a punto de costarle la vida. Desde la corte se articuló de inmediato un relato oficial del suceso para acallar rumores y transmitir un mensaje de tranquilidad. El asunto se convirtió pronto en materia literaria gracias a varios escritores foráneos y españoles, que minimizaron el impacto negativo de la noticia y aprovecharon para reforzar la imagen de un rey protegido por la Providencia. En este trabajo se estudian algunos de esos escritos y se edita una carta escrita poco después del suceso.

Palabras clave: Atentado de Barcelona; Fernando el Católico; Isabel la Católica; propaganda regia; Carlo y Marcelino Verardi; Pedro Mártir de Anglería; Lucio Marineo Sículo; Andrés Bernáldez; Pere Miquel Carbonell; Hernando de Talavera; Fernán Álvarez de Toledo; Alonso Ortiz; MSS 7076 BNE 


\section{LA CONFORMACIÓN DE UNA IMAGEN REGIA APROPIADA}

Mucho se ha escrito sobre el excelente manejo de la propaganda por parte de los Reyes Católicos ${ }^{1}$. Sin embargo, antes de cifrar todo su éxito en la eficaz maquinaria propagandística que les rodeó, vale la pena detenerse en el análisis detallado de los mensajes que supieron difundir y, sobre todo, atender al proceso de creación de una imagen regia idealizada que, sin duda, no se asentó solo en la pura ficción. A nadie se le escapan las estrechas relaciones que existen entre la literatura, como generadora de iconos o mitos, y la vida real: si la literatura se alimenta de hechos y realidades, esos sucesos, una vez pasados por su tamiz, ejercen un poderoso influjo sobre los vivos. Fernando e Isabel no fueron inmunes al influjo de los modelos que les brindaban las crónicas, los relatos del pasado y los propios textos que surgían a su alrededor. Al mismo tiempo, fueron muy conscientes de la necesidad de utilizar todos los medios a su alcance para difundir una imagen positiva de sus personas, juicios e intereses.

Cuando los poetas cortesanos comparaban en sus versos latinos a Fernando con Eneas, Hércules, Alejandro Magno o Jasón, lo empujaban, de algún modo, a emular las virtudes propias de esos héroes antiguos sin parangón en el presente. En el caso de Isabel, las lecturas piadosas, a las que fue tan aficionada (y entre las que se incluían las vidas de santos), le brindaban igualmente modelos de fortaleza y de fervor religioso con los que armar su ánimo ante las muchas adversidades que se le presentaban. Estos cruces entre la literatura y la vida siempre son un camino de ida y vuelta: cuando los poetas o escritores perfilan con sus imágenes y, sobre todo, con sus consejos un personaje, proponen al destinatario de sus obras una identificación con la imagen creada; de ahí nace la obligación moral de actuar en consonancia con ese modelo. Cuanto mayor sea esa identificación, mayor será la vigencia de esa imagen ideal. En los Reyes Católicos hay propaganda, pragmatismo y utilización sagaz e inteligente de su propia imagen. Mas su éxito no se asienta solo en esa sagacidad e inteligencia. El éxito de su mensaje tuvo mucho que ver, como indica Fernández de Córdova, con «la coherencia de su discurso y la Realpolitik»². Los re-

1 Vid. José Manuel NieTO SORIA, Ideología y representación del poder regio en la Castilla de fines del siglo XV, en Estudios de historia de España, 8 (2006), pp. 133-162; (ed.), Orígenes de la monarquía bispánica. Propaganda y legitimación (1400-1520), Madrid, 1999; Apología y propaganda de la realeza en los cancioneros castellanos del siglo XV. Diseño literario de un modelo político, en En la España Medieval, 11 (1988), pp. 185-222.

2 Vid. Álvaro FERNÁNDEZ DE CóRDOva, La emergencia de Fernando el Católico en la Curia papal: identidad y propaganda de un príncipe aragonés en el espacio italiano (1469-1492), en Aurora EGIDO- 
yes asumieron un papel que representaron a la perfección, pero no hay que olvidar que estaban profundamente convencidos de su misión providencial y salvífica, de la que habían oído hablar y sobre la que habían leído; de ahí que parte de su tarea consistiese en transmitir y trasladar esa creencia íntima y los proyectos políticos de ella emanados a sus súbditos.

Si esta necesidad de hacerse visible y transmitir nuevos mensajes cobra sentido cada vez que un nuevo monarca accede al trono, mucho más cuando las circunstancias no son las más favorables. Isabel y Fernando sabían mucho de ello, pues su llegada al trono no fue nada sencilla. De entrada, tuvieron que justificar un matrimonio sancionado mediante una bula falsa. Luego, tras la muerte de Enrique IV, se vieron obligados a hacer frente a una auténtica guerra civil en la que se había inmiscuido Portugal. Las fracturas surgidas tras esas contiendas eran muchas y profundas, por lo que se hizo necesario y urgente cerrar filas, crear un proyecto conjunto (Castilla y Aragón iban ahora de la mano), darlo a conocer y ponerlo en marcha: la lucha contra los musulmanes del Reino de Granada, presentada como una de las últimas cruzadas europeas para añadir a la cristiandad tierras ocupadas por los mahometanos, fue ese primer proyecto. Tras Granada, y así se hizo saber, vendría la conquista definitiva de Jerusalén, que, según prometían muchas profecías divulgadas desde los siglos medievales, supondría el advenimiento de una nueva era de paz que se prolongaría por más de mil años ${ }^{3}$.

Para otorgar credibilidad a estos ambiciosos proyectos, solo había que acomodar los actos a las ideas, tarea fácil para príncipes convencidos desde niños de su excepcionalidad. Los éxitos se iban jalonando uno tras otro y la convicción de que contaban con el apoyo divino parecía más que evidente. Al hilo de esa creencia, aumentaron los escritos cuya función última era difundir esos mensajes (mesiánicos unos y providencialistas otros) y crear una corriente de simpatía general hacia los soberanos y sus proyectos. El primer gran escollo en esta marcha triunfal que iba a llevar a Fernando hasta Tierra Santa fue el atentado sufrido por el monarca en Barcelona en diciembre de 1492: ¿era este un primer indicio de que la estrella del rey se agotaba y perdía el apoyo de la Providencia? Como se

José Enrique Laplana (eds.), La imagen de Fernando el Católico en la Historia, la Literatura y el Arte, Zaragoza, 2014, pp. 29-81 (p. 32).

3 Sobre los mensajes providencialistas y mesiánicos propios este periodo, vid. Eulàlia DURAN-Joan REQUeSEns, Profecia i poder al Renaixement. Textes profettics catalans favorables a Ferran el Catòlic, Valencia, 1997; Alain Milhou, Colomb et le messianisme hispanique, Montpellier, 2007. Aunque centrado en la generación previa, resulta muy útil César OlIVERA SERRANO, Mesianismo y profetismo en Portugal y Castilla (ca. 1380-1430). Notas para su estudio, en Sémata. Ciencias Sociais e Humanidades, 26 (2014), pp. 359-382. 
verá, esa idea fue pronto desterrada y el suceso, narrado y poetizado de inmediato por los hombres de letras, recibió lecturas positivas. Una vez más, las imágenes narradas y los mensajes escritos fueron clave para impulsar las políticas regias, que, tras Granada, tenían pendiente el conflicto con Francia y, por ende, la participación en los asuntos de Italia.

\section{LOS REYES CATÓLICOS, EJEMPLO DE VIRTUDES, AMADOS DE LA PROVIDENCIA}

Pero vayamos por partes y detengámonos en la percepción de ambos soberanos como reyes virtuosos y, por eso mismo, merecedores del favor divino. Lo cierto es que, para poder mostrarse ante sus súbditos como excelentes soberanos, Isabel y Fernando debían cultivar en público (y en privado) aquellas virtudes que los definían como tales. Los specula principum, tan exitosos a partir del siglo XIII, mostraban cuáles eran esas virtudes y cómo emplearlas para ejercer un buen gobierno. A estos escritos de carácter teórico, salidos muchos de ellos de la pluma de egregios hombres de iglesia, se sumaba el discurso moral de Aristóteles, propalado en la Edad Media gracias a santo Tomás, pero reactualizado a través de las nuevas traducciones hechas directamente a partir de los textos griegos, como la de Leonardo Bruni.

De ese modo, las tradicionales virtudes morales o cardinales (prudencia, justicia, fortaleza y templanza) recibieron un nuevo enfoque a la luz de ese pensamiento aristotélico, que sacaba a la palestra virtudes como la liberalidad o la magnificencia. Obras como el Isagogicon moralis disciplinae de Leonardo Bruni (1423) o el Memoriale virtutum de Alfonso de Cartagena (ca. 1425) presentan de manera clara y didáctica las virtudes de las que debía hacer gala a cualquier príncipe u hombre de estado nuevo. El hilo conductor en ambas obras es la Ética a Nicómaco pasada por el tamiz de Cicerón, erigido en nuevo modelo de comportamiento ciudadano, sin descuidar, por supuesto, una dimensión cristiana siempre presente. Dejadas a un lado las virtudes teologales, que atañen a la vida individual, interesan en primer término las virtudes con una clara dimensión social, pues el rey, el príncipe o el noble están a la cabeza de un estado y deben procurar la felicidad de sus súbditos ${ }^{4}$. Ello implica que sea la justicia, a la que le corresponde velar

4 Guido CAPELLI, Conceptos transversales: república y monarquía en el Humanismo político, Res publica, 21 (2009), pp. 51-69 y en Exemplar mundi: el principe renacentista como «ejemplo del mundo», en Despalabro: Ensayos de humanidades, 5 (2011), pp. 129-137, ha dedicado numerosos trabajos a las teorías políticas del Renacimiento y, en especial, a la teoría del organicismo político, que presenta 
por el bien común, una de las virtudes más alabadas. El reparto equitativo de las dádivas y la asignación a cada uno de lo que le corresponde es la mayor garantía de tranquilidad para todos ${ }^{5}$. No es extraño, por tanto, que los Reyes Católicos hicieran alarde de su calidad como jueces, una manera de mostrar con toda pompa y esplendor la calidad de su poder.

Ahí están las sentencias ejemplares dictadas por Isabel durante su estancia en Sevilla, sentada bajo un dosel en pleno agosto ${ }^{6}$. Tampoco les tembló la mano en Galicia a la hora de condenar a muerte a algunos nobles desobedientes y levantiscos. Una curiosidad adicional: el día en que sufrió su atentado, Fernando había estado, como dice el cronista Andrés Bernáldez, «oyendo el pueblo» desde las ocho de la mañana hasta las doce. Algo que también corrobora Miquel Carbonell en la carta a Bartomeu de Verí, en la que se refiere a la costumbre de escuchar los jueves a los «pobres miserables» que se acercaban ante él «per aconseguir justicia dels deutes» ${ }^{7}$. Una costumbre, a medio camino entre la piedad y el sentimiento de lo justo, de la que también se hace eco Pulgar en su Crónica de los Reyes Católicos, cuando en su semblanza del rey Fernando afirma que «de su natural condición era inclinado a hacer justicia y también era piadoso y se compadecía de los miserables» (cap. XXIII) ${ }^{8}$. Del mismo modo, dada la naturaleza de la obra, el elogio a la justicia real no falta en el De rebus Hispaniae memorabilibus de Lucio Marineo",

la sociedad como microcosmos o cuerpo humano en el que al rey le corresponde el papel de la cabeza. En dicha concepción política no se propugna ni la lucha ni el conflicto, pues el cuerpo social aspira a la perfecta armonía entre la cabeza (el soberano) y los distintos miembros del cuerpo (los súbditos). Esto no significa que el rey pueda hacer lo que quiera, ya que está sometido al escrutinio constante de los nobles y el pueblo, que lo «aceptarán únicamente si sabe ejercer las virtudes» (Guido CAPELLI, Exemplar mundi [supra], p. 130).

5 Alfonso de Cartagena dedica un largo excurso a la justicia en la tercera cuestión de su Duodenarium, donde analiza de manera pormenorizada las principales virtudes de los buenos soberanos (vid. Luis Fernández Gallardo y Teresa Jiménez Calvente, El Duodenarium (c. 1442) de Alfonso de Cartagena: cultura castellana y letras latinas en un proyecto inconcluso. Estudio, edición y traducción, Córdoba, 2015, pp. 275-308.

6 Recoge esta anécdota Luis SUÁREZ FERNÁNDEZ, Claves históricas en el reinado de Fernando e Isabel, Madrid, 1998, p. 177. También aborda el estudio de esta virtud asociada a la reina Miguel Ángel LADERO QUESADA, Isabel la Católica vista por sus contemporáneos, en En la España Medieval, 29 (2006), pp. 225-286 (pp. 268-276).

7 Vid. Angel Sesma, Los idus de diciembre de Fernando II. El atentado del Rey de Aragón en Barcelona, Zaragoza, 2006, p. 187.

8 Fernando Pulgar, Crónica de los Reyes Católicos, Zaragoza, 1567, fol. 18 (he consultado una edición facsímil, Zaragoza, 1987).

9 Lucio Marineo Sículo, De rebus Hispaniae memorabilibus, Alcalá de Henares, 1530 (cito por la traducción castellana, De las cosas memorables de España, Alcalá de Henares, 1539, en la edición facsímil de la editorial Órbigo, s. a.). 
en que hay un capítulo entero titulado «De la nueva manera de justicia que los cathólicos príncipes inventaron contra los delinquentes» (lib. XIX, fol. 150r); más adelante, se incluye también un largo excurso sobre la Inquisición y el problema de los judíos, entendido como algo que atañía a la justicia: «Del castigo y justicia de los Reyes Cathólicos contra los ereges» (fols. 163r-165) y, finalmente, en el libro XXI, un auténtico panegírico sobre las virtudes de los soberanos, se vuelve sobre la justicia en «De cómo los Reyes Cathólicos restituyeron la justicia en sus reinos» (fol. 183r).

Junto a la justicia, se sitúa la fortaleza, indispensable para quien debe batirse con las armas y tiene la obligación moral de lograr una fama imperecedera. Ahora bien, el rey no solo ha de ser valiente y arrojado en justas y torneos, en los que, según Pulgar, Fernando no tenía rival. Es indispensable que esa valentía se demuestre en la defensa del reino frente a las amenazas externas. Desde muy tierna edad, las circunstancias del reino de Aragón, en pie de guerra con Cataluña desde 1461, lo habían habituado a las armas, que manejó con destreza. Más adelante, su matrimonio con Isabel le hizo abrazar nuevas empresas bélicas, en las que sobresalió como perfecto caudillo al frente de sus tropas y como valiente soldado. Fue esta una de las virtudes más celebradas del monarca, según se pone de manifiesto en numerosos textos, como en la oda de Antonio Geraldini, donde se destacaba su actitud y precoz victoria en la batalla de Calaf ${ }^{10}$, o en los poemitas épicos escritos a la luz de la guerra de Granada por Paulo Pompilio o Ugolino Verino, en los que esta faceta de guerrero ejemplar es la clave sobre la que articular todos los elogios ${ }^{11}$.

De igual modo, también la reina debía presentarse ante sus súbditos como una mulier fortis. Sin embargo, era opinión común que las virtudes femeninas no podían medirse con el mismo rasero que las masculinas: si los hombres debían ser fuertes y valientes fuera de casa, el ámbito femenino del hogar limitaba su fortaleza a la defensa denodada de la castidad y a su capacidad para encajar las desgracias personales con dignidad. Sin embargo, en el caso de Isabel cabía hacer algunas excepciones: en primer lugar, porque se trataba de una reina que ejercía un gobierno efectivo; en segundo lugar, porque ella misma había dado muestras en más de una ocasión de un fuerte carácter: su designación como princesa heredera, su

10 Vid. Martin FrüH, Profecía y realidad: una oda de Antonio Geraldini al rey Fernando el Católico, en Dietrich BrEISEMEISTER-Axel SCHÖNBERGER (eds.), De litteris Neolatinis in America Meridionali, Portugallia, Hispania, Italia cultis, Fráncfort, 2002, pp. 47-67.

11 Vid. Teresa JIMÉNEZ CALVENTE, Fernando el Católico: un béroe épico con vocación mesiánica, en Aurora EGIDO-José Enrique LAPLANA (eds.), La imagen de Fernando el Católico... [ver n. 2], pp. 127165 . 
determinación a la hora de contraer matrimonio o su propia coronación como reina de Castilla son fruto de esa naturaleza arrojada ${ }^{12}$. Desde Castilla, se potenció además una imagen de la reina que, como las heroínas de la Antigüedad, mostraba una doble fortaleza: la castidad, sobre la que no cabía albergar duda alguna, y la valentía propia de un varón en la defensa de su reino. Esta imagen de reina guerrera fue especialmente destacada en la guerra contra Portugal y alcanza, con matices, las campañas granadinas. Cuando en 1487 Pere Boscà describe la toma de Málaga en su oratio $^{13}$, sitúa a la reina en el campamento militar, proveyendo a las tropas de todo lo necesario desde el punto de vista material y espiritual. Ella es la que crea los primeros hospitales de campaña y expulsa del campamento a los tahúres y las mujeres de mala reputación para mejorar la moral de las tropas. Valera afirma igualmente en su crónica que Isabel examinaba junto a su esposo el estado de las operaciones ${ }^{14}$. La reina, modelo de fortaleza y valentía, reconfortaba con su ejemplo y oraciones a quienes partían para la lucha y era capaz de soportar las mismas penalidades que sus hombres. Es más, en boca de todos corría la voz de que su sola presencia, con un inobjetable valor taumatúrgico, era señal clara de la caída inminente de la ciudad ${ }^{15}$.

Un paso más dan los que nos la describen desde fuera; así, Paolo Pompilio la compara con Semíramis por su faceta de mujer aguerrida y fundadora de ciudades; y Ugolino Verino la representa al lado de su esposo pasando revista a las tropas ${ }^{16}$. Para este poeta italiano, la reina destaca por su ardor guerrero y por su capacidad para arengar a los soldados antes de la batalla ${ }^{17}$. En sus versos vemos a

12 Basta recordar el comentario recogido por Alonso de Palencia en su crónica cuando presenta al rey Fernando contrariado por la ceremonia escogida por Isabel para proclamarse reina de Castilla; en dicha ocasión, Gutierre de Cárdenas llevó la montura de Isabel de las riendas y en la mano una espada desnuda, como símbolo de que ella no dudaría en ejercer el poder sobre sus súbditos: «Todos sabemos que se concedió a los Reyes; pero nunca supe de Reina que hubiese usurpado este varonil atributo» (Alonso de Palencia Alonso de Palencia, Crónica de Enrique IV, III, 1, t. 3, Antonio PAZ Y MeLIA, Madrid, 1904-1908, p. 317.

13 Pere Boscà, Oratio Petri Bosca artium et sacre theologie doctoris R. D. Cardin. S. Marci auditoris Rome habita xi. Kal'. Nouembris ad sacrum Cardinalium Senatum Apostolicum in celebritate uictorie Malachitane per serenissimos Ferdinandum et Helisabeth Hispaniarum principes catbolicos feliciter parte anno Christi M.cccc.lxxxviii, Roma, 1487.

14 Diego de Valera, Crónica de los Reyes Católicos, ed. Juan de Mata Carriazo, Madrid, 1927, p. 249.

15 Nicasio Salvador Miguel La conquista de Málaga (1487). Repercusiones festivas y literarias en Roma (Publications of eHumanista), Santa Bárbara, 2014, pp. 20-1.

16 Vid. Teresa Jiménez Calvente, Fernando el Católico... [ver n. 11], p. 166.

17 Vid. Inmaculada López CalaHorro (ed.), Ugolino Verino, De expugnatione Granatae, Granada, 2002, pp. 75-85. 
una auténtica virgo bellatrix que lucha por expulsar a los musulmanes y defender a los cristianos, una imagen que se repite en otros elogios de la reina escritos en Italia, como en las cartas de Cassandra Fedele ${ }^{18}$. Lo mismo dice otro italiano afincado en España, pues, según Antonio Geraldini, en su Oratio in obsequio nomine Ferdinandi et Elisabeth Innotentio VIII exbibito (Roma, 1486), la reina vivía en el campamento donde desarrollaba la actividad propia de un general («et ducis optimi munus implet» [fol. 5r]).

Las otras dos grandes virtudes cardinales, prudencia y templanza, destacan igualmente en ambos soberanos, especialmente la primera. Ambos son considerados muy «capaces» (adjetivo que gustó especialmente a Gracián para definir una de las principales virtudes de Fernando en el Político). Esa prudencia o sabiduría para las cosas del gobierno se fortaleció gracias a su habilidad para dar a conocer sus logros por medio de las letras o a través de las artes plásticas. La sagacidad y la capacidad para convencer a propios y extraños de sus proyectos e ideas son puestas de relieve por el propio Maquiavelo en el retrato que ofrece de Fernando en el cap. XXI de su Príncipe. Este da un paso más, y frente a la opinión común, defiende que el rey, astuto y taimado, se servía torticeramente de los ideales religiosos en beneficio propio, sin reparar siquiera en la posible crueldad de alguna de sus decisiones, como la expulsión de los judíos, un hecho alabado, no obstante, por otros muchos tratadistas:

Oltre a questo, per potere intraprendere maggiore imprese, servendosi sempre della religione, si volse a una pietosa crudeltà cacciando, spogliando, del suo regno e' marrani [...] E così sempre ha fatte e ordite cose grandi, le quali hanno sempre tenuti sospesi e ammirati gli animi de' subditi.

Aquí se desliza la idea de que Fernando siempre disfrazó su ambición desmedida bajo el ropaje de la religiosidad. Es difícil calibrar el alcance exacto de su fe, que nos sitúan en el ámbito de las virtudes teologales, pero las opiniones de Maquiavelo también hay que situarlas en su contexto, por ser un leal defensor de su Florencia natal, firme aliada de Francia, con la que España y sus reyes mantenían duras disputas ${ }^{19}$. Sin embargo, no cabe duda de que, en sinceridad religiosa,

18 Vid. Álvaro FERnÁNDEZ DE CóRdova, El 'Rey Católico' de las primeras guerras de Italia. Imagen de Fernando II de Aragón y V de Castilla entre la expectación profética y la tensión internacional (14931499), en Medievalismo, 25 (2015), pp. 197-232 (p. 208).

19 Sobre la actitud de Maquiavelo hacia Fernando, del que traza un retrato no tan halagüeño como se ha venido diciendo, vid. Miguel SARALEguI, El príncipe afortunado: Fernando el Católico en la obra de Maquiavelo, en M. ${ }^{a}$ Idoya ZOZORRa (ed.), Virtudes políticas en el Siglo de Oro, Pamplona, 
Isabel se llevó la palma, haciendo gala de una virtud especialmente femenina ${ }^{20}$. Ante todo, no hay que olvidar que la pareja se presentó siempre como una conjunción o simbiosis de fuerzas, donde a cada uno le correspondía una tarea propia, así que Fernando podía estar tranquilo: Isabel era la encargada de rezar por los dos para obtener el favor de Dios y de los santos gracias a su intermediación. Esa imagen caló hondo y, de hecho, en el poema que Antonio de Nebrija dedicó a los Reyes Católicos por su peregrinación a Santiago en 1486, la Peregrinatio ad divum Iacobum, se describe a la reina rezando mientras el rey lucha con los musulmanes ${ }^{21}$. Gestos en este sentido no faltaron, pues, como relatan los diferentes cronistas, durante las campañas granadinas se estableció la costumbre de que, nada más tomar cualquier ciudad o fortaleza, los monarcas procedían a dar gracias a Dios tras colocar en el lugar más alto de la villa un pendón con la señal de cruz, mientras los sacerdotes entonaban un Te Deum.

Una última virtud sobre la que se volverá más adelante es la clemencia, cuyo ejercicio solo está al alcance de los grandes gobernantes, a quienes se les elogia si, en un gesto último de generosidad, son capaces de perdonar a sus enemigos. Esta virtud fue elogiada en la Antigüedad por autores tan autorizados como Cicerón, que la convirtió en el elemento central de su Pro Marco Marcello, o Séneca, que le dedicó un tratado completo. La revitalización de estos autores y la conexión de esta virtud pagana con la templanza explican que no falten menciones a la clemencia de los Reyes Católicos, siempre representados como soberanos justos

2013, pp. 29-48. Un buen resumen sobre lo que Maquiavelo opinaba del rey Fernando se lee en Antonio GaRgano, La imagen de Fernando el Católico en el pensamiento histórico y político de Maquiavelo y Guicciardini, en Aurora EGIDO-José Enrique LAPLANA (eds.), La imagen de Fernando el Católico... [ver n. 2], pp. 83-104. El texto citado lo tomo de aquí. Muy interesante resulta el estudio introductorio de Juan Manuel FUERTE MONGE, Maquiavelo. El principe. El arte de la guerra. Discursos sobre la primera década de Tito Livio. Vida de Castruccio Castracani. Discurso sobre la situación de Florencia tras la muerte del Foven Lorenzo Médicis, Madrid, 2010.

20 Sobre este particular, vid. Juan Antonio PRIETO SAYAGUÉs, El mecenazgo femenino en los monasterios y conventos de Castilla (1350-1474): poder y espiritualidad, en Miguel GARCÍA-FERNÁNDEZ y Silvia CERNADAS MARTÍNEZ (eds.), Reginae Iberiae. El poder regio femenino en los reinos medievales peninsulares, Santiago de Compostela, 2015, pp. 193-222, donde estudia los ejemplos de religiosidad ofrecidos por las reinas de Castilla, que se presentaban como modelos para sus sucesores y para otras mujeres nobles. A este respecto resultan muy clarificadoras las palabras de Lucio Marineo, que afirma que la reina mostraba «tanto ardor y diligencia» en el culto divino que, a pesar de estar ocupada en la gobernación de su reino, «parecía que su vida era más contemplativa que activa» (Lucio Marineo, De rebus... [ver n. 3], XXI, fol. 183r).

21 Teresa JimÉnez Calvente, Nebrija, poeta áulico: la Peregrinatio Regis et Reginae ad Sanctum Iacobum. Edición, traducción y estudio, en Medievalismo 20 (2010), pp. 63-95. 
y clementes ${ }^{22}$. Así, Sigismondo dei Conti, al hablar de la conquista de Málaga en su Historiae suorum temporum, VIII, xiii, pondera la extrema clemencia del rey, que perdonó a muchos vencidos a pesar de que podría haberlos condenado a muerte de aplicar el derecho de guerra ${ }^{23}$. Poco después, en 1492, todos cuantos relatan el atentado sufrido por el monarca recuerdan su gesto de clemencia extrema al pedir que no se ejecutase al traidor. Aunque a nadie se le escapa que, en esta ocasión, mantener al criminal con vida era esencial para averiguar todo lo posible sobre el suceso (así lo declara Mártir en sus cartas), se insistió mucho en alabar la clemencia del rey, una idea que caló hondo; de hecho, se cuela incluso en los romances, como se ve en el que trata atentado del $\mathrm{rey}^{24}$, donde el soberano hace gala de su clemencia en dos momentos fundamentales: en el momento mismo del atentado («itate!, ¡tate! No le maten/ porque el caso sea sabido», vv. 23-4) y, lo que es más significativo, al conocer la dura sentencia contra el criminal ( $\ll$ La ciudad dice que muera/ el rey nunca ha consentido/ viendo que por necedad/ el caso había cometido», vv. 63-6).

A estas cuatro virtudes tradicionales había que añadir, para amoldarse a los nuevos tiempos, la magnificencia y liberalidad de las que habla Aristóteles y que en algunos tratados de época, como en el libro III del Duodenarium de Alfonso de Cartagena o en el Memoriale virtutum del mismo autor, reciben la consideración de virtudes propias y exclusivas de los príncipes ${ }^{25}$. Ser generoso en la concesión

22 Es curioso que ese mensaje de la justicia contrapesada con la clemencia sea una de las lecturas más aceptadas de la granada empleada por Enrique IV como divisa con el lema de «agro dulce». Sobre este asunto, vid. Sagrario LóPEZ POZA, La divisa de las granadas del rey Enrique IV de Castilla y su estela posterior, en Imago. Revista de emblemática y cultura visual, 6 (2014), pp. 81-95, quien recuerda, entre otros textos, los Emblemas morales de Juan de Horozco (1589) o las Empresas morales de Juan de Borja (1680), quienes insisten en que la granada con su sabor agridulce es un símbolo del poder real que ha de ser riguroso con la justicia al tiempo que clemente, guardando un difícil punto medio. Según esta estudiosa, la granada que aparece en el escudo de los Reyes Católicos no solo haría referencia a la importante conquista del reino nazarí, pues bien podría incorporar el sentido que ya le otorgaba Enrique IV.

23 Bien es sabido que gran parte de los cautivos fueron reducidos a la esclavitud y entregados como recompensa a los que habían participado en la contienda, que pudieron quedarse con ellos o venderlos en pública subasta (vid. Nicasio SALVAdor MiguEL, La conquista de Málaga... [ver n. 7 ], pp. 90-1).

24 Vid. Jorge BeRGUA, Romancero español. Colección de romances selectos desde el siglo XIV hasta nuestros días, Madrid, 1995, pp. 147-8.

25 No deja de ser significativo que Lucio Marineo Sículo, De rebus... lib. XIX-XXI, [ver n. 9], al ponderar las virtudes regias, se extienda mucho más en la liberalidad y magnificencia que en la justicia o fortaleza. Sobre la magnificencia y la liberalidad propia de reyes en el Duodenarium de Cartagena, vid. Luis FernándeZ Gallardo-Teresa JimÉnEZ Calvente, El Duodenarium... [ver n. 5], pp. 293 y ss. 
de premios a quienes lo merecen y espléndido a la hora de costear edificios públicos, iglesias y monasterios eran virtudes privativas de unos pocos: los reyes y nobles. Cualquiera que conozca el reinado de los Reyes Católicos comprueba hasta qué punto llevaban bien aprendida la lección, pues ambos dieron alas a una ambiciosa política de obras públicas, con edificios que engalanaron con sus escudos y empresas, como una forma muy efectiva de propagar las excelencias de su gobierno. Otra faceta más de esa generosidad es el apoyo brindado a los hombres de letras en general. En este campo, tampoco se quedaron atrás ambos monarcas, mecenas de estudiosos y poetas, que recibieron gracias a esa labor el elogio y el agradecimiento de muchos autores del momento. Los soberanos establecieron relaciones estrechas con algunos de esos eruditos y expertos en leyes, muchos de ellos funcionarios cualificados, que se convirtieron en peones indispensables para el desarrollo de las políticas regias ${ }^{26}$.

El boato cortesano y el gasto en ropajes, banderolas y otros signos externos de poder fueron una manifestación más de esa liberalidad extrema de la que debían hacer gala los soberanos, por más que los comentarios sobre la austeridad, cuando no tacañería de Fernando, son muy abundantes. Un capítulo en el que no fallaron tampoco fue en el de proporcionar a las iglesias y monasterios todo el ajuar necesario para las celebraciones del culto, sobre todo en aquellas ciudades y villas recién ganadas para la cristiandad, con lo que la generosidad de los soberanos se aliaba aquí con una sincera y profunda piedad religiosa, según exponía Geraldini al papa Inocencio VIII en su ya mencionada Oratio:

quanta magnificentia non solum templorum apparatus et augusta ornamenta verum etiam sacerdotum ordo, dignitas et sedulitas declarant imprimisque testantur lautissime vestes et preciosa vasa ad templa que in hostili agro nuper erecta fuerunt paulo ante transmissa (fol. $5 \mathrm{v})$.

Lo mismo recuerda Lucio Marineo en su crónica de los Reyes Católicos, donde dedica un apartado entero del cap. XIX a «los templos que los Cathólicos

26 Esta especial situación de los eruditos salidos de las universidades en la corte de los Reyes Católicos ha sido estudiada y puesta de relieve por Pedro M. CÁTEDRA, La literatura funcionarial en tiempos de los Reyes Católicos, en Antonio CHAS Aguión y Cleofé TATO (eds.), Siempre soy quien ser solía: Estudios de literatura española medieval en homenaje a Carmen Parrilla, La Coruña, 2009, pp. 57-82. También Guido CAPELLI, 'Sapere et potere': L'umanista e il principe nell'Italia del Quattrocento, en Cuadernos de filología italiana, 15 (2008), pp. 73-91, ha retratado y estudiado la peculiar situación de los humanistas en las cortes a las que acudieron y en las que vivieron ofreciendo sus servicios a quienes pudieran necesitarlos, una relación que dejó huella en numerosos escritos. 
Príncipes edificaron y de otros que repararon y restauraron». Así, cuenta la generosidad con que los monarcas erigieron nuevos templos en las tierras recién conquistadas y cómo incluso invirtieron una considerable suma en construir un templo en Roma:

Teniendo los Cathólicos Príncipes guerras muy iustas y muy sanctas empresas por augmentar la religión Christiana, para que más fácilmente venciesen sus enemigos y alcançassen dellos victoria, no solamente hazían oraciones e sacrificios a Dios todo poderoso y a su bendita madre nuestra señora Virgen sin manzilla y a muchos sanctos, mas también prometían muy liberalmente de hazer cosas sagradas y nuevos templos. Por lo qual Dios siempre cumplía sus votos y muy sanctos desseos. [...] Finalmente en Roma de aquel cabo del río Tíbre cerca de la puerta de Sant Pancracio hizieron un magnífico templo que se dice de sant Francisco, que costó gran suma de dineros. Gastaron así mismo gran tesoro en el reparo de la iglesia y hospital que en Roma se dize Santiago de los Españoles (Marineo, De rebus..., lib. XIX, fol. 166r).

Este retrato se amplía más adelante, cuando, en un repaso sistemático a las virtudes más señaladas de los soberanos (la justicia, clemencia, humanidad, fortaleza y paciencia), se insiste en «la liberalidad y magnificencia de los Reyes Católicos», lib. XXI, fol. 183v-184r, con las que superaron, a su entender, a cuantos reyes y hombres habían sido. En el haber de esta generosidad estarían las dotes otorgadas a las doncellas, sus espléndidas limosnas a los pobres, sus regalos a embajadores, «los thesoros que gastaron por espacio de quarenta años en las guerras continuas que tuvieron»y, en especial, su apoyo a Ferrante de Nápoles en Otranto frente a los turcos.

En definitiva, todas las excelentes virtudes tenían habitación en los soberanos y, según sus voceros, las poseían en su grado más excelso. Tanto derroche de virtud y tal cumplimiento solo podían explicarse como un favor del cielo, que los había enviado a la tierra y a sus reinos para ser espejos en los que mirarse y garantizar la paz y la concordia entre sus súbditos. Pero su meta no se detenía ahí, porque su misión religiosa era, a la postre, mucho más ambiciosa, ya que solo se vería satisfecha con la expulsión de los musulmanes de los territorios cristianos y la conquista de Jerusalén:

Dei amorem et cultum omnibus deliciis universisque divitiis preferentes laboriosum sane ac difficile sed meriti et glorie plenum opus aggressi sunt, Christi Salvatoris sui nomen et imperium domi forisque propagare (Geraldini, Oratio, fol. $4 \mathrm{v})$. 


\section{UN REY PUESTO A PRUEBA: POEMAS, CARTAS Y PRIMEROS RELATOS SOBRE EL ATENTADO DE BARCELONA}

Si los reyes cumplían, como daban a entender, con todos esos objetivos y se mostraban además como modelos de virtud en cada una de sus actuaciones, lógico era pensar que la Providencia cumpliría con su parte del trato en una suerte de eficaz do ut des. Al fin y al cabo, los éxitos encadenados de Isabel y Fernando eran una prueba inequívoca de que la protección divina los alcanzaba. Es casi seguro que los monarcas creían en esa protección, por lo que hablaron de ella sin tapujos y espolearon a otros para que también lo hicieran. Un cronista tan cercano a los reyes como Lucio Marineo se atrevió incluso a interpretar la historia pasada como una sucesión de acontecimientos luctuosos que solo podían preparar el camino para estos monarcas salvíficos, según reza en el capítulo titulado «De las cosas, causas y misterios que procedieron para que los Reyes Católicos por la divina Providencia remediasen los males de España»:

Assí que de lo susodicho manifiestamente comprehendemos y nos consta que tuvo Dios especial cuidado y providencia de conservar y ayuntar a estos Cathólicos príncipes para que socorriessen y remediassen las cosas de España que se iva a perder y para resistir y castigar a los enemigos de la fe cathólica y diesen amparo, defensa y socorro a los buenos, justiciassen los malos y librassen el reyno de Granada de las manos que servían al nephandíssimo nombre de Mahoma (Marineo, De rebus... [ver n. 9], XXI, fol. 181v).

En este ambiente heroico, mesiánico y exaltado, las dificultades de la lucha se tornaron en pruebas de valor: cuanto más difícil era un asedio o la toma de alguna ciudad más claramente se percibía que la Providencia o, si no, su brazo ejecutor, la Fortuna, se ponían siempre del lado de los soberanos ${ }^{27}$.

$\mathrm{Al}$ final, todos los presagios favorables confluyeron en 1492. En los primeros días del año, se hizo efectiva la rendición de Granada, esperada por todos desde la caída de Baza y Almería en diciembre de 1489. En Roma, los enviados especiales de los reyes actuaron con enorme celeridad y difundieron con éxito las noticias del triunfo de aquella cruzada encabeza por España y secundada por toda Euro-

27 En aquellos momentos, la Fortuna adquirió una enorme resonancia por ser considerada una delegada directa de la Providencia o de Dios mismo, con capacidad para favorecer el ascenso o caída de algunos nobles y «castigar los abusos de poder». Sobre la importancia de Fortuna en el siglo XV en la literatura y en la sociedad castellana, vid. Guillermo FERNÁNDEZ RODRÍGUEZESCALONA, Fortuna y sociedad en la literatura del siglo XV, Madrid, 1992. 
$\mathrm{pa}^{28}$. Enseguida se hizo saber que aquello no había terminado, pues de inmediato se proyectó la extensión de la guerra al norte de África hasta alcanzar Jerusalén. Y, como una señal más de esa buena estrella y de que la Providencia había fijado sus ojos en España, 1492 también saludó la llegada al papado de Alejandro VI, de origen español. A medida que avanzaba el año, una nueva noticia llenó a todos de contento: el descubrimiento de nuevas tierras en el occidente. Con este último jalón, el rey Fernando, además de guerrero y pacificador, se convertía, como bien indica Fernández de Córdova, en un auténtico evangelizador, pues ahora se añadirían a la cristiandad nuevas tierras sin necesidad de guerra alguna ${ }^{29}$.

Con todos estos triunfos en la mano, no es de extrañar que el rey pusiese rumbo a Barcelona por varios motivos, como bien ha explicado Sesma en su excelente estudio ${ }^{30}$. Había llegado la hora de entrar con toda la pompa y honores en una ciudad que a menudo se le había mostrado esquiva ${ }^{31}$. Además, era preciso negociar ya con el rey de Francia todo lo relativo a la devolución de los condados del Rosellón y la Cerdaña. Para la ocasión, Fernando se hizo acompañar de la reina Isabel, sus tres hijas, el príncipe Juan y un amplio séquito de nobles, que fueron recibidos por el obispo de Gerona con exclamaciones de alegría: «la vinguda de Vuestra Magestat en aquest principado representa la incarnació de Jesucrist». Hora era también de que el príncipe Juan, heredero de la corona de Castilla y de Aragón, entrase en la ciudad de manera triunfal (su anterior visita, en 1480, siendo un niño, había sido deslucida y casi clandestina ${ }^{32}$ ).

Aquella entrada tuvo lugar el día 19 de octubre de 1492. Pocos días después, el 7 de diciembre, un payés, Juan de Cañamares, atentó contra el rey que había estado toda la mañana impartiendo justicia en el Palacio de la Diputación ${ }^{33}$.

28 Para las fiestas con que se celebró esa victoria y para todo lo relativo a la presencia española en Roma, Álvaro FERNÁNDEZ DE CóRDOVA, Alejandro VI y los Reyes Católicos. Relaciones políticoeclesiásticas (1492-1503), Roma 2005. Del mismo autor también, La imagen de los Reyes Católicos en la Roma pontificia, en En la España Medieval, 28 (2005), pp. 259-354.

29 Para estudio pormenorizado y certero de las distintas imágenes del rey Fernando en Italia en estos momentos, vid. Álvaro FERNÁNDEZ DE CÓRDOVA, El 'Rey Católico' de las primeras guerras... [ver n. 18].

30 Ángel SESMA, Los idus... [ver n. 7].

31 Así, cuando en 1479 acudió a la ciudad para ser recibido como el nuevo rey de Aragón, justo el día 23 de septiembre, alguien clavó en la puerta de la capilla de las Vírgenes una proclama «instando a los barceloneses a alzarse en nombre del rey de Francia» (Ángel SESMA, Los idus... [ver n. 7] p. 31).

32 Vid. Ángel Sesma, Los idus... [ver n. 7], pp. 44-5..

33 Los pormenores del atentado son bien conocidos: la cuchillada en el cuello, la función casi providencial del collar que desvió la trayectoria, las primeras medidas adoptadas, las recaídas en la recuperación del soberano, la condena del traidor. Para todo estos detalles, vid. Ángel SESMA, 
De la alegría se pasó al susto y, de ahí, al miedo: «Tant és estada la commoció, plor, tristicia e dolor de aquesta ciutat de Barcelona, divendres a VII del mes de decembre any MCCCCXCII, que escriptura exprimir no poria», en palabras de Miquel Carbonell a Bartomeu de Verí en la carta que le envió el día siguiente del suceso $^{34}$. La noticia corrió como la pólvora y, casi de inmediato, se construyó un articulado discurso sobre este suceso: en primer lugar, desde el punto de vista de la política interna, había que desterrar la idea de que se trataba de una conspiración. Era preciso poner de manifiesto que ni los barceloneses ni los catalanes en general estaban detrás de tan terrible hecho. Por ello, todos los relatos insisten en que Juan de Cañamares había actuado solo, sin ayuda de nadie, llevado por un arrebato de locura. En otras palabras, Fernando el Católico era un príncipe admirado y venerado por todos sus súbditos, sin excepciones, y contaba con el apoyo unánime de su gente.

Sentada esta premisa, había que explicar de manera clara y contundente, con la vista puesta fuera, aunque también en clave interna, cómo un rey elegido y protegido por la Providencia, que debía negociar en aquellos días con el monarca francés la devolución de los condados (y, de paso, el asunto de Nápoles) y que pretendía lanzar una nueva cruzada hasta Jerusalén, había estado a punto de morir de manera violenta justo en el momento de mayor gloria. En este capítulo, la engrasada maquinaria de escritores cortesanos entró en escena y se afanó en dotar a este suceso de un significado trascendente y positivo. Surge así una rica literatura en torno al atentado que, aunque en lo esencial transmite un mensaje idéntico, adquiere diferentes matices en función del público al que va dirigido.

Quienes escriben en latín, por lo general poetas y eruditos foráneos, se dirigen a un público extenso y refinado, de dentro y fuera de España, acostumbrado a las modas literarias impuestas por el humanismo. Estos autores, en especial los poetas, envuelven su relato con un aparato quasi mitológico para difundir un mensaje político fácilmente descifrable. En sus manos, el atentado no es más que el trasunto de una lucha mucho más relevante entre el Bien y el Mal: una vez más,

Los idus... [ver n. 7], pp. 47-123. Vid. también Pierre GENESTE, L'attentat de Barcelone contre le roi catholique, en Cabiers du monde bispanique et luso-brésilien, 27 (1976), pp. 147-158, y M. Dolores RINCÓN, «Discite nunc igitur, reges, aeterna mereri nomina»: una interpretación del atentado de Barcelona de 1492, en Axel SCHÖNBERGER-Klaus ZimmERMANn ed., De orbis Hispani linguis litteris historia moribus. Festschrift für Dietrich Briesemeister zum 60. Geburtstag, Fráncfort, 1994, pp. 567-576.

34 El texto de Carbonell lo tomo de Ángel SESMA, Los idus... [ver n. 7], pp. 186-90. Aunque la carta lleva fecha del 8 de diciembre, la última parte de la misma se escribió con posterioridad de acuerdo con los hechos que en ella se cuentan, probablemente el 12 de ese mismo mes. 
el espíritu del género épico lo inunda todo y, de ese modo, se consigue que la figura de Fernando, el Elegido, salga engrandecida tras derrotar a las fuerzas del Mal. Esto es lo que, de manera clara, expone Carlo Verardi en su carta al cardenal Mendoza para dedicarle una obra teatral, el Fernandus Servatus, cuando le dice que la divina Providencia lo había permitido «ut regis virtus enitesceret et inter adversa illustrior fieret» ${ }^{35}$. En la misma línea, están el Pluto furens de Mártir de Anglería, con un título harto significativo, y el poema de Ugolino Verino, Gratulatio christianorum de incolumitate Ferdinandi regis. Se intuyen relaciones entre los tres textos, aunque, como ha señalado Beyer ${ }^{36}$, no hay pruebas irrefutables que así lo avalen. Sea como fuere, da la impresión de que la obra teatral de los Verardi antecedió a las otras y les sirvió de inspiración.

En su pieza teatral, Carlo y Marcelino Verardi echan mano de un elaborado aparato mitológico-alegórico y, con un gran conocimiento de los clásicos, componen una «tragicomedia», en la que se percibe nítida la huella del In Rufinum de Claudiano, que le presta la idea inicial de un conciliábulo de las fuerzas del Mal para destruir al héroe, que, por supuesto, vence. Beyer observa también la influencia de las Divinae institutiones de Lactancio ${ }^{37}$, clave para entender el principal argumento de la obra: el atentado al rey no pone en duda su capacidad como gobernante cristiano, sino que sirve para poner a prueba su virtud, una idea que antes del cristianismo se hallaba en el De providentia de Séneca y que se convirtió en un auténtico lugar común.

La obra se plantea como una tragedia, porque trata de asuntos históricos protagonizados por un rey, y al mismo tiempo como una comedia, porque tiene

35 Existe una edición y traducción moderna al inglés de la obra de Verardi de Gary GRUND, $H u$ manist Tragedies (The I Tatti Renaissance Library, 45), Cambridge, MA/London, 2011, pp. 244 y ss. También hay una edición y traducción al italiano (vid. Maria Domenica MuCI, Marcellino Verardi, Fernandus Servatus. Edizione critica, traduzione e comento, Florencia, 2007, que ofrece un interesante estudio y comentario del texto).

36 Un magnífico y exhaustivo estudio de las obras de Verardi y Pedro Mártir de Anglería es el de Hartmut BEYER, Das politische Drama im Italien des 14. Und 15. Fabrbunderts. Humanistiche Tragödien in ibrem literatischen und funktionalen Kontext, Münster, 2008, pp. 389-494. Más resumido e igual de interesante es su Carlo and Marcellino Verardi's Fernandus Servatus and the Poem Supra casum Hispani regis by Petrus Martyr: Drama and Diplomacy in Papal Rome under Alexander VI, en Jan Bloemendal, Peter G. F. Eversmann y Elsa Strietman (eds.), Drama, Performance and Debate. Theatre and Public Opinion in the Early Modern Period, Leiden, 2013, pp. 35-56 (p. 48).

37 En este punto, BEYER Carlo and Marcellino Verardi's... [ver n. 35], pp. 44-5, reproduce las palabras de Carlo Verardi en el proemio de su obra, donde dice: «yo había leído a menudo en los textos sagrados que la envidia de los demonios se ensaña más con los hombres buenos que con los malvados» («Legeram namque saepe in sacris litteris daemonum inuidiam potius in uiros probos quam facinorosos saeuire»). 
un final feliz. Fernando sale fortalecido y engrandecido tras el atentado en el que se adivina la mano del propio Demonio (Pluto), que se sirve de un pobre loco llamado Ruffus (un reconocible guiño a la obra de Claudiano) para llevar a cabo sus planes. Pero ni este ni su mentora, la furia Tisífone, han podido hacer nada contra el Rey, que cuenta con la protección divina y, en especial, con la del Apóstol Santiago. Así las cosas, cabe preguntarse cuáles eran las motivaciones del Diablo y sus Erinias, para atacar al soberano, y la respuesta es sencilla: el deseo de venganza, porque Fernando le había arrebatado uno de sus feudos más queridos, Granada, de donde los musulmanes, considerados aquí esbirros de Satanás, habían sido expulsados. Tras esta lucha, el monarca sale reconvertido en un auténtico héroe merecedor del respeto de todos, incluido el papa Alejandro VI, invitado de honor en la primera representación de la pieza.

Esto explica que, en la última escena, aparezcan el rey Fernando, la reina Isabel y el cardenal Mendoza, a quien está dedicada la pieza. Isabel pregunta por el destino del traidor; Fernando dice desconocerlo, y Mendoza da detalles de la locura manifiesta del reo. La terrible descripción de los signos de la posesión infernal del condenado da pie a Fernando para afirmar que, sin duda alguna, la Providencia lo había salvado de semejante horror para encomendarle una tarea aún mayor. Por ello, para devolverle el favor, Fernando promete proseguir la guerra en el norte de África hasta alcanzar Tierra Santa. Tras esta declaración de intereses, un coro cierra la pieza con el elogio de la virtus interrita del rey, capaz de arrostrar todos los peligros, hasta el punto de que, de ahora en adelante, nadie podrá atreverse a atacarlo jamás:

Haec nos conciliat superis, haec scandere coelum aethereasque docet sedes, super astra uolare nos facit et numquam sentit communia fata (vv. 496-8)

[Esta virtud suya nos reconcilia con los dioses celestes.

Esta nos enseña a ascender a las etéreas moradas del cielo; nos hace sobrevolar las astros, y no experimenta jamás los destinos comunes].

Aunque la representación terminaba con este canto premonitorio, lleno de buenos presagios, la edición impresa incluye también una invectiva en dísticos elegíacos contra el traidor Rufo, a quien se compara con todos los criminales, tiranos y hombres depravados de la Antigüedad ${ }^{38}$. Frente a tanta maldad, las virtu-

38 La invectiva ha sido estudiada por M. Dolores RINCÓN, La presencia de Claudio Claudiano en una invectiva (1493) de Marcelino Verardi, en Jesús LUQUE-M. Dolores RINCÓN-Isabel VELÁZQUEZ (eds.), Dulces Camenae. Poética y Poesía Latinas, Granada, 2012, pp. 805-814. 
des del rey Fernando brillan con más fuerza. Estas, unidas a los rezos de su esposa, habían logrado el beneplácito los Superi, artífices de la salvación del soberano. Llegados a este punto, el poeta pide a Hispania que ejecute la sentencia y castigue al criminal, contra el que, en ningún caso, se actuará con falta de clemencia, pues lo justo es que un rey inocente viva sin temor a los malvados ( $«$ Crede mihi nulla est, nulla inclementia. Fas fit/ innocuo regi non timuisse malos»). Dicho de otro modo: solo la muerte del criminal podrá restablecer el orden roto y la justicia quebrantada. La clemencia del rey y su fortaleza quedaban del todo intactas.

A pesar de que la obra se concibió como una pieza teatral, no faltan en ella los ingredientes propios de la épica de inspiración virgiliana, que explica, entre otras cosas, que se recurriese al hexámetro dactílico (502 versos), metro nada adecuado para la poesía dramática de inspiración clásica: si el pius Eneas contó con el amparo de su madre Venus, Fernando se ha salvado gracias a la intermediación de Santiago. Uno y otro son ejemplos cumplidos de virtud, que es puesta a prueba por la ira rencorosa de Juno o, en esta ocasión, por el mismo Diablo. El Fernandus servatus responde, además, a una clara intencionalidad política, que se explica tanto por el momento en que se concibió como por el espacio elegido para su representación. El atentado tuvo lugar justo cuando había que negociar con Francia la devolución de los condados y cuando las ambiciones de ambos soberanos se cernían sobre Italia. Sin lugar a dudas, el rey Fernando necesitaba contar con el apoyo del papa, al que había que recordar que el soberano, firme defensor de la cristiandad, seguía contando con el beneplácito y favor de la Providencia. En cuanto al espacio pensado para la representación, fue la propia Roma, posiblemente en febrero o marzo de $1493^{39}$, en el palacio del cardenal Rafael Riario, fautor de los españoles y muy amigo de los miembros de la Academia de Pomponio Leto, grandes aficionados al teatro.

El planteamiento de Verardi gustó y es posible que Pedro Mártir de Anglería lo tuviese en cuenta para componer su Pluto furens, un poema en hexámetros (654 versos), que también nos presenta a Plutón fuera de sí y deseoso de vengarse del rey Fernando ${ }^{40}$. Para lograrlo, el señor de los infiernos recurre a las Furias

39 Sobre las fechas de representación, vid. Hartmut BEYER, Carlo and Marcellino Verardi's... [ver n. 35], p. 47, quien recuerda el papel de Mendoza como mediador en el conflicto que enfrentó al rey Fernando y al papa Alejandro a cuenta del nombramiento de nuevos obispos en España. Las diferencias quedaron finalmente selladas el 27 de marzo de 1497. Esto explicaría, en parte, que la obra se dedicase al influyente cardenal.

40 Ha sido Hartmut BEYER, Carlo and Marcellino Verardi's... [ver n. 35], el más firme defensor de la precedencia de la pieza teatral sobre el poema de Mártir de Anglería, rebatiendo las teorías de José Luis GOTOR, Il 'Carmen de Casu regis' de Pedro Martire de Angleria e la tragicommedia 'Fernan- 
y, en especial, a Alecto, encargada de volver loco al payés y empujarlo al crimen (en la obra de Verardi la furia elegida era Tisífone). Con todo, el poeta milanés introduce una pequeña variación, pues los valedores del rey son nada menos que la Virgen María y su hijo. Aunque, como apunta Beyer ${ }^{41}$, es más que probable que Mártir de Anglería tuviese noticias de la obra teatral representada en Roma a través de alguno de sus amigos italianos o españoles de la curia (el propio cardenal Mendoza pudo darle cuenta del texto), no hay que cifrarlo todo en esa dependencia directa, pues, como se verá de inmediato, la idea de que el demonio había instigado el atentado está ya en los primeros escritos expedidos desde la corte. Dicho de otro modo, los Verardi arroparon y engalanaron con su ficción literaria y buen quehacer poético una idea que se había transmitido dentro y fuera de España ${ }^{42}$. Ni qué decir tiene que Pedro Mártir de Anglería también estaba al tanto de esa forma de explicar el suceso. Así que los tres poetas lo tuvieron muy fácil para utilizar como punto de partida de sus respectivos poemas los mensajes oficiales, en los que desde el principio se habló de la participación directa del diablo.

A partir de aquí, se aprecian algunas diferencias en cuanto al sentido y significado del poema de Mártir, quien sugiere que esa dura prueba no tenía por objeto único y principal encumbrar al monarca y mostrarlo como un protegido de la Providencia, garante de sus futuros éxitos. El poema del milanés encierra

dus servatus' di Marcellino Verardi, en La rinascita della tragedia nell'Italia dell' umanesimo: Centro di Studi sul Teatro Medievale e Rinascimentale: Atti del IV Convegno di Studio di Viterbo, Viterbo, 1983, pp. 159-184 y 185-203. Desgraciadamente, el Pluto Furens carece aún de una edición definitiva, pues la de Ursula HECHT, Der 'Pluto furens' des Petrus Martyr Anglerius. Dichtung als Dokumentation (Studien zur klassischen Philologie), Fráncfort, 1992, no tuvo en cuenta el manuscrito que se conserva en la Biblioteca Vaticana, el Barb. lat. 1705 (vid. Hartmut BEYER, Carlo and Marcellino Verardi's... [ver n. 35], p. 40), y desconocía la primera edición del poema en Burgos ca. 1498, a cargo de Lucio Marineo Sículo (Teresa Jiménez Calvente, Pedro Mártir de Anglería y su poema bistórico Equestria, en Humanistica Lovaniensia, 42 [1993], pp. 71-101 [p. 74, n. 4]; Un siciliano en la España de los Reyes Católicos. Los Epistolarum familiarium libri XVII de Lucio Marineo Sículo, Alcalá de Henares, 2001, p. 349). Además de esta edición hubo otras dos: una en Sevilla en 1511, al cuidado de Nebrija, y la última en Valencia en 1520, preparada por Alonso de Proaza. Hecht se limita a reproducir simplemente el texto de esta última edición.

41 Vid. Hartmut BEYER, Carlo and Marcellino Verardi's... [ver n. 35], pp. 49-50.

42 En el diario de Giovanni BURCARDO, Diarium sive rerum urbanarum commentarii, 1483-1506, t. III, se recoge que la noticia del atentado llegó a Roma diez días después de haberse cometido. El 27 de diciembre le fue comunicada al papa la recuperación del monarca en unas cartas enviadas por el obispo de Badajoz. Por ese motivo, el 29 de diciembre, el pontífice ordenó una misa en honor de la Virgen por la salvación del soberano en Santa María de Febribus. En ese mismo diario se recoge la noticia de que el atentado había sido instigado por el demonio, que se le había aparecido a Juan de Cañamares bajo la forma de un ángel en los últimos doce años y le había ordenado matar al rey (vid. Maria Domenica MUCI, Fernadus servatus [ver n. 35], p. XVIII). 
también una intención propedéutica y moralizante al mostrar al rey su propia humanidad y conminarle a la humildad y penitencia, según expone Jesús a su madre. El mensaje parece claro: los reyes han de responder de sus actos ante Dios, por lo que siempre han de actuar con nobleza y virtud, una idea presente igualmente en los documentos emanados de la corte, donde tanto la reina como sus allegados hicieron una lectura moral del suceso ${ }^{43}$.

Lo que sí distingue estas dos obras de otros escritos, y eso es precisamente lo que las relaciona más estrechamente, es que ambas encierran un mensaje político dirigido al papa Alejandro VI para inducirle a prestar su apoyo a los reyes de España ante Francia y en Italia. Al fin y al cabo, el papa Alejandro VI era el destinatario último del poema, como explica Pedro Mártir en su carta dedicatoria al prelado, donde señala que Diego López de Haro le había encargado esos versos sobre el atentado para hacérselos llegar al papa durante su embajada en Roma en junio de 1493.

Llegados a este punto, dejo para otra ocasión el análisis en profundidad de estos textos en verso y me centraré en los mensajes que se difundieron en prosa y, por lo general, en lengua vernácula dentro de España (aunque incluyo también aquí las cartas de Pedro Mártir en latín). Los escritores que se sirven del vernáculo narran con gran detalle el atentado y trufan su discurso con consideraciones morales sobre la brevedad de la vida y el poder igualador de la muerte, que alcanza a todos sin distingos. Lejos de un mensaje grandilocuente, estos relatos invitan a la reflexión, la humildad y la penitencia, que han de cumplir los reyes y todos sus súbditos para granjearse de nuevo el favor divino. En ellos se ofrece, desde un principio, una explicación lógica al episodio (la locura del autor del atentado es la clave) y se descarta de antemano cualquier tipo de conspiración. En un ambiente de exaltación regia, era obligado hacer una lectura positiva de aquel acto violento. A la postre, el atentado constituía un buen motivo para dar gracias a Dios por haber librado al soberano de la muerte $y$, como apunta Álvarez de Toledo (tras el que se escucha la voz de la propia reina), por haber permitido que las virtudes del rey se pusieran de manifiesto. Tales afirmaciones iban encaminadas a restaurar la confianza general en que la Providencia había estado en todo momento del lado del soberano y que, en el futuro,

43 Ursula Hecht, Der 'Pluto furens'... [ver n. 38], pp. 83-85, define el poema de Mártir como un panegírico con un carácter didáctico, pues pondera las virtudes magníficas de los reyes y encierra una profunda enseñanza, que se desgrana precisamente en el parlamento de Cristo (vv. 280-360). 
seguiría siendo así, siempre y cuando todos adoptasen una actitud más piadosa y una religiosidad más sincera.

Esto es lo que hacen Carbonell en su carta a Verí, incluida como cierre de su Chronica de Espanya, o Pedro Mártir en sus letras latinas a Hernando de Talavera, al conde de Tendilla y Ascanio Sforza (ep. 125, 126, 127 y 131) para darles cuenta del suceso ${ }^{44}$. En la primera, Mártir apostrofa a ambos próceres y les recuerda los casos de altos reyes y señores envenenados o asesinados por traidores (Alejandro Magno, Pompeyo y César), lo que ha de hacerles pensar en la fugacidad de la vida humana, idea que retoma tanto en su segunda misiva al conde como en la dirigida a Sforza (ep. 127 y 131). En esa primera carta, Mártir de Anglería, testigo de los hechos, narra con brevedad lo sucedido y da cuenta de las primeras reacciones de la reina: preparar una flota para poner a salvo al príncipe Juan, acudir al lado de su esposo y reclutar una legión de médicos para velar por la salud del rey. La segunda misiva, dirigida en exclusiva al arzobispo de Granada y escrita nueve días después del atentado, es una buena prueba de la ansiedad con que se debió de vivir la recuperación del monarca en medio del incesante ir y venir de noticias y rumores durante aquellos días ${ }^{45}$. Tras repetir lo ya sabido sobre la autoría del atentado, Mártir de Anglería, en un nuevo ejercicio de estilo, informa al prelado sobre una recaída del monarca que ha tenido a todos en vilo. Estas dos cartas adquieren un relieve especial y responden, sin duda, a una de las preocupaciones más acuciantes de la reina en los primeros

44 Las cartas pueden leerse en la traducción de José LÓPEZ DE TORO (ed.), Pedro Mártir de Anglería, Epistolario. Libros I-XIV, epístolas 1-231 (Documentos inéditos para la Historia de España, tomo IX), Madrid, 1953, pp. 226-228 y 238-9.

45 A este grupo de cartas pertenece también la de Alonso Martínez de Angulo en nombre de la ciudad de Córdoba al rey Fernando para mostrarle la tristeza y preocupación de la villa ante las noticias del atentado. De ese modo, como señala Pedro CÁTEDRA, La literatura funcionarial... [ver n. 26], pp. 74-76, Angulo mostraba al rey el profundo dolor y la enorme preocupación por un acto que había sacudido a todos. Lo mismo ocurre con las misivas enviadas por los jurados de la ciudad de Gerona a la reina para expresarle su dolor y comunicarle que habían mandado detener a un sobrino del reo a fin de interrogarlo (vid. Lluis BATLLE Y PRATS, El atentado contra Fernando el Católico y el municipio gerundense, en Cuadernos de Historia ferónimo Zurita, 19-20 [1966-67], pp. 231-39). En ambos casos, no se trata de cartas personales o escritas en el entorno de la corte sino de epístolas que reflejan las relaciones de las ciudades y villas con los monarcas. De hecho, Alfonso Ortiz, en su Tratado de la herida del rey, elogia a la reina por ocuparse de inmediato de que «todos los grandes de vuestros reynos, todas vuestras cibdades en un tiempo oviessen noticia verdadera del caso inopinado» (cito por el ejemplar de la BNE, inc. 1905, p. 3, col. A). Se puede leer una transcripción del texto en Ángel SESMA, Los idus... [ver n. 7], pp. 193-206). Del mismo modo, para convencer a todos de que el rey estaba a salvo, este escribió personalmente algunas cartas a las villas y ciudades, para dar cuenta del suceso. 
momentos, durante los que temió que la difusión de la noticia en Granada trajese aparejados disturbios. Ante esa suposición, se consideró de vital importancia mantener bien informados a quienes ejercían allí el poder efectivo ${ }^{46}$.

El deseo de controlar la información para acallar los rumores y el afán de transmitir un mensaje tranquilizador y esperanzado están también en la base de la carta que la propia reina ordenó escribir a su secretario Fernán Álvarez de Toledo, dirigida al conde de Cifuentes, Juan de Silva y Castañeda, el 13 de diciembre (un día después del ajusticiamiento del criminal) ${ }^{47}$. En ella se contiene el que, a todas luces, puede considerarse el relato oficial del atentado tal y como se formuló en la propia corte a los pocos días de haber sucedido los hechos. Fernán Álvarez de Toledo lo cuenta todo con sumo detalle: recoge las primeras hipótesis (que todo había sido un error, porque las puñaladas iban destinadas a un individuo del entorno del $\mathrm{rey}^{48}$ ); destaca el papel de la reina, encargada de organizar con rapidez los interrogatorios (no faltaron tormentos ni testigos) y da cuenta del castigo ejemplar aplicado al criminal. El secretario real se hace eco incluso de las declaraciones de Cañamares, ante la presión de los miembros del Consejo, y fruto de las torturas. Este afirmó que, veinte años atrás, había tenido un «revelamiento, quele había parescido un hombre en manera de fuego, el qual le dezía que era el Spíritu Sancto, e le dezía quél

46 Por el contrario, la carta a Sforza es un efectivo relato del suceso. En ella, da cuenta de los temores de todos ante la posible muerte del monarca; alude a la confesión del reo e incluso describe su propia visita al criminal, que le pareció «un anciano», con «ojos porcinos, negros, penetrantes, arrugados», un auténtico loco, en definitiva. Mártir le cuenta también que, aunque el rey quiso perdonarlo, se ejecutó la dura sentencia. Aunque nada se puede aventurar, pues se desconoce la fecha exacta de la misiva, se observan ciertas analogías entre esta descripción del loco y la que ofrece Verardi en su poema por boca de Mendoza (ambos insisten en su torva y oscura mirada).

47 A este respecto conservamos dos cartas: una de la reina al conde, para explicarle que, ante su interés, le mandará un relato detallado del suceso escrito por su secretario, Fernán Álvarez de Toledo; la otra es la carta o informe redactado por el mencionado secretario. Ambos textos, la carta de la reina y el relato del secretario forman parte de la colección diplomática del ilustrado Juan Bautista Muñoz, que se conserva en la Real Academia de la Historia. El texto fue transcrito como apéndice a la edición del Libro de la cámara real del príncipe don fuan e officios de su casa e serviçio ordinario de Gonzalo FERNÁNDEZ DE OvIEDO, editado en Madrid, 1870, pp. 193 196. Sobre Fernán Álvarez de Toledo, merece la pena consultar el erudito y bien documentado estudio de Carmen VAQUero, Fernán Álvarez de Toledo, secretario de los Reyes Católicos. Genealogía de la toledana familia Zapata, Toledo, 2005, pp. 120-21, que sitúa al secretario junto a la reina en Barcelona en esos días.

48 Esta idea aparece incluso en la carta que el propio rey Fernando dirige a la ciudad de Huesca el mismo 7 de diciembre: «vino por las espaldas y no se sabe si conoció a nos» (vid. Ángel SESMA, Los idus... [ver n. 7], p. 90. 
era Rey y le mandava que non se confesase» ${ }^{49}$. Solo la insistencia y empeño de muchos religiosos consiguieron que el reo aceptase la confesión el día previo a la muerte, momento en que recobró la cordura y reconoció que «por espíritu diabólico se había movido».

La conclusión que se extrae de estos datos es clara: que el demonio había sido el verdadero instigador del atentado, una idea que constituye el argumento principal sobre el que, como se ha visto, se construyeron los poemas latinos sobre este suceso, y que circuló ampliamente por la corte papal. De todo ello cabía concluir que, en última instancia, Dios había permitido aquel acto violento «porque más se mostrase a todo el mundo la fe e devoçión, constancia, esfuerzo, animosidad, paçiençia e otras muchas e grandes virtudes que en su alteza hay». Dicho de otro modo, las virtudes del rey necesitaban un campo de batalla para mostrarse en todo su esplendor, por lo que la misma Providencia había propiciado aquella lucha desigual en la que el oponente era el propio Satanás.

Otra carta sumamente interesante y muy reveladora es la que la propia Isabel escribió a su confesor Hernando de Talavera el 30 de diciembre; en esta misiva, la tercera carta de las que la reina envió en esos días al fraile jerónimo, Isabel desvela sus pensamientos y sentimientos más íntimos ${ }^{50}$. Si las cartas son, como decían los tratados al uso, una imagen del que la escribe, aquí se dibujan la fortaleza, piedad, humildad y la firme confianza en Dios de la soberana. Como el atentado es una prueba manifiesta de que la muerte puede alcanzar a los reyes en cualquier momento, la reina quiere arreglar sus asuntos más terrenos; por ello pide a su confesor que haga una lista de sus deudas monetarias para poder saldarlas todas lo antes posible ante el temor de una muerte repentina (en la adenda final indica que su secretario personal, Álvarez de Toledo, le había confeccionado un listado, pero aún así deseaba que el fraile lo completase).

49 No deja de llamar la atención que esta afirmación coincide con lo dicho por san Pablo cuando advierte de que Satanás puede presentarse bajo el aspecto de un «ángel de luz» (II Cor 11, 14-15: «ipse enim Satanas transfigurat se in angelum lucis»).

50 Las cartas las dio a conocer por primera vez fray José de Sigüenza, historiador de la orden jerónima, que refiere cómo tuvo acceso a los autógrafos de la propia reina conservados en la biblioteca de El Escorial. Dichos autógrafos se perdieron y hoy podemos leerlas a través de distintas copias. Vicente Rodríguez VALENCIA, Isabel la Católica en la opinión de españoles y extranjeros. Siglos XV al XX, 3 t, Valladolid, 1970, t. 3, pp. 31-34, llevó a cabo una edición de las cartas de la reina a partir de las copias encontradas en El Escorial (ms. L-I-13, 9r-18r) y en la BNE (ms. 175, $227 \mathrm{v}-231 \mathrm{v})$. La sinceridad de estas misivas se corrobora con la nota final de la carta fechada el 30 de diciembre, en la que la reina especifica aún más sus peticiones y pide a su confesor que destruya la misiva: «Ruegoos que sea para vos solo, que con este propuesto se haze. Plega a Dios que luego nos veamos sin daño de lo de allá y de lo de acá quanto Dios fuere seruido». 
Descargada su conciencia, la reina da cuenta de sus sentimientos más profundos y de sus vaivenes emocionales en esos días aciagos: al conocer el atentado, su primera preocupación fue por la ciudad de Granada; por ello, quiso ponerse en contacto lo antes posible con su confesor, para que viniese a su lado. Este sería el contenido de una primera carta, escrita nada más conocer los hechos, pero que no conservamos. Si aquellas palabras fueron fruto de la precipitación, cuando aún no había visto a su esposo, poco a poco todo se fue calmando, pues Dios hizo que la herida no fuese mortal. Cuenta así los pormenores de los últimos días, con mejorías (narradas en una segunda carta tampoco conservada) y una recaída, justo el séptimo día, que hizo temer lo peor. Una vez pasado el peligro y restablecido el rey, viene esta última misiva (la tercera, que aquí se comenta), en la que la reina agradece a Dios su generosidad y revela su creencia firme en que era ella la merecedora del castigo divino y no su esposo:

no sé cómo siruamos a Dios esta tan gran merced, que no bastarían otros de mucha virtud a seruir esto, ¿qué haré yo que no tengo ninguna? Y esta era vna de las penas que yo sintía, ver al Rey padecer lo que yo merecía no mereciéndolo él, que pagaua por mí. Esto me mataua de todo ${ }^{51}$.

Un último apunte más: ante los rumores sobre una posible conspiración, la reina certifica a su confesor que el atentado ha sido obra de un individuo solo. Se afirma lo que ya se sabe, que aquel loco había intentado matar al rey, inspirado, según las propias palabras del reo, por el Espíritu Santo. Una vez más, aparece la faceta más piadosa de la reina: como el condenado no quería confesarse ni tampoco nadie lo quería confesar, preocupada por la salvación de su alma, envió a unos frailes, para que «le trajesen a que se confesase, y con mucho trabajo lo trajeron a ello». La confesión le devolvió la razón y el deseo del perdón (esto mismo se decía en la carta de Álvarez de Toledo). De todo ello se extrae también una única conclusión: que todo había sido obra de Dios, «que nos quiso castigar con más piedad que yo merezco». Como indica Sesma ${ }^{52}$, la reina se ahorra los pormenores macabros de la cruel ejecución, sobre los que sí se extendieron Carbonell, Álvarez de Toledo y Pedro Mártir en su carta a Sforza. La razón de ese silencio es evidente: ante su confesor, la reina no postula una intervención de la Providencia para poner a prueba las

51 Cito por la edición de Vicente Rojo VALENCIA, Isabel la Católica... [ver n. 33], p. 33, aunque, para facilitar la lectura del texto, lo acentúo y puntúo de acuerdo con las normas actuales. También reproduce la carta, aunque tomándola del Epistolario español, Madrid, 1917, pp. 14-15, Ángel SESMA, Los idus... [ver n. 7], p. 193.

52 Vid. Ángel SeSMA, Los idus... [ver n. 7], p. 119. 
virtudes de su esposo, una opinión que, dentro de un diálogo íntimo entre la reina y su confesor, podría sonar a pura soberbia. Por el contrario, ella adopta una actitud humilde y piadosa al hacer recaer sobre su cabeza todas las culpas (y no parece que aquí haya solo un deseo de mostrarse como mujer religiosa). Al fin y al cabo, esta carta no es sino una confesión en diferido y por escrito, no un relato formal pensado para la difusión inmediata de determinados mensajes y consignas.

Aún hay que añadir a todas estas cartas otra curiosa misiva, muy diferente en tono y contenido a las anteriores, copiada al final de la traducción castellana de la Ética a Nicómaco conservada en el ms. 7076 de BNE y que edito al final de este trabajo $^{53}$. En ella, se menciona el atentado como un momento crucial en la vida de los soberanos, porque es una circunstancia en la que Dios los había puesto a prueba. Sin embargo, no se trata de una epístola escrita con la intención de narrar el suceso, aclarar pormenores o propalar ciertas consignas: aquí estamos ante una petición a la reina para que, en un asunto sobre el que nada sabemos, no se deje llevar por la ira o los malos consejeros ${ }^{54}$. En definitiva, la carta es un ejemplo claro de hasta qué punto esas consignas oficiales sobre el significado profundo del atentado habían calado hondo.

Las crónicas de la época, en castellano y latín, también ofrecen narraciones detalladas del atentado ${ }^{55}$. Andrés Bernáldez, Lucio Marineo Sículo o el propio Miquel Carbonell en su carta a Verí oficializan un relato en el que dejan claro que

53 No están aquí todos los textos en que se da cuenta del atentado. En aquellos días, hubo un ir y venir continuo de cartas para interesarse por la salud del Rey. Entre estas, están las cartas que fueron y vinieron a Gerona, editadas por Lluís BATLLE Y PRATS, El atentado contra Fernando... [ver n. 31]. Por ellas conocemos que, en los días siguientes, fue detenido también un sobrino de Cañamares, que a la postre resultó inocente.

54 La carta fue dada a conocer por Ángel GómEZ Moreno, El reflejo literario, en José Manuel Nieto Soria (ed.), Orígenes de la monarquía... [ver n. 1], pp. 315-340. Para más información sobre el manuscrito, vid. BETA (Bibliografía Española de Textos Antiguos: Philobiblon) <http:/ /sunsite. berkeley.edu/Philobiblon/BETA/1475.html> [consultado en noviembre de 2016].

55 No incluyo aquí los relatos sobre el atentado escritos por Jerónimo Zurita o Pedro Abarca, entre otros, que no son coetáneos a los hechos y que construyeron sus narraciones a partir de los historiadores previos. No es este el caso de Gonzalo Fernández de Oviedo, quien afirma haber presenciado los hechos, según cuenta en sus Batallas y Quinquagenas (manejo la edición de Juan Bautista AVALLE ARCE, Salamanca, 1989, pp. 346-347). Este hace hincapié en la conmoción que sacudió Barcelona, donde todos se echaron a la calle con las armas en la mano para cobrarse una supuesta venganza. Su relato de las primeras reacciones tras el atentado es el más detallado y completo; aquí se refieren las primeras decisiones adoptadas por la reina (y aquí coincide con lo dicho por Mártir de Anglería) y por los miembros más allegados de su corte (don Manrique de Lara, el Cardenal Mendoza, el infante don Fernando de Granada, «hermano del rrey que la perdió»). Fernández de Oviedo muestra aquí su habilidad como narrador al componer un breve cuadro dialogado con el que sabe transmitir la confusión reinante en los primeros instantes tras conocerse la noticia. 
el autor del mismo fue un pobre loco que solo, sin ayuda de nadie, decidió matar al rey. Los datos que ofrecen y los detalles minuciosos sobre el autor, la herida, la convalecencia, el clamor general de la ciudad de Barcelona en apoyo al rey y el castigo ejemplar infligido al criminal coinciden. También son comunes las expresiones de gratitud a Dios, que no había permitido la muerte del monarca. Como era de esperar, el suceso se lee en clave providencialista, al considerar que, al fin y al cabo, aquel susto había sido un simple aviso para devolver a los reyes el sentido de la humildad. Esto es especialmente acusado en Marineo, que narra este suceso dentro del capítulo dedicado a la ensalzar la «fortaleza y paciencia» de los reyes. Por eso destaca la actitud clemente de la reina, que quiso que el reo, sentenciado a morir «por tenazas ardientes», fuera primero ahogado, para que no sufriese tanto: «primero le ahogasen y después le atenazasen para cumplir la sentencia de la justicia» (De rebus... [ver n. 4], lib. XXII, fol. 186r).

Este dato no lo corroboran ni Bernáldez ni Carbonell, que sí ofrecen, en cambio, una narración detallada de los terribles tormentos infligidos al penado por las calles de Barcelona. La inclusión o no de esos detalles macabros se explica por el carácter particular de cada uno de estos relatos. Andrés Bernáldez muestra su habilidad para recrear con dramatismo unos hechos que había conocido indirectamente a través de fuentes escritas o por vía oral. A él, como memorialista más que cronista $^{56}$, le interesa captar en todo momento la atención del lector, para lo que combina la narración con la recreación de aquellos lamentables hechos; implica al lector en lo ocurrido mediante apóstrofes, insiste en la ausencia de conspiración y destaca que el atentado tuvo lugar días antes de que se iniciasen las negociaciones con Carlos VIII, un asunto que le interesa, por lo que subraya que el monarca, a pesar de su dolor, nunca lo dejó de lado («empero no cessó la demanda») ${ }^{57}$. Al igual que Carbonell, testigo presencial de los hechos, el Cura de Los Palacios otorga al castigo una función ejemplarizante, pues eso es lo que puede esperar quien se opone al poder real. No deja de ser llamativo que Carbonell escogiese esa carta suya a Verí como cierre o broche de su Chronica, tal vez para resaltar el duro trance que sufrió el monarca y el castigo terrible de quien quiso matarlo. Frente ambos,

56 Sobre el carácter particular de la crónica del Cura de Los Palacios, Fernando GómEz REDONDO, Historia de la prosa de los Reyes Católicos: el umbral del Renacimiento, t. 1, Madrid, 2012: 116-140.

57 De todos los relatos, quizá sea el de Andrés Bernáldez el más extenso, detallado, y dramático, pues en su afán de dotar de dinamismo a la narración, incluye pequeñas frases en estilo directo, como las palabras del rey que, nada más sentir la herida, pidió socorro a la Virgen María $\left(\ll_{i} \mathrm{O}\right.$ Santa María y valme!») o sus voces para evitar un ajusticiamiento inmediato del criminal. También oímos la turbación de la gente y los primeros rumores sobre el posible criminal, que reconoce que el diablo le decía al oído que, si mataba al rey, él sería coronado en su lugar. 
Marineo solo aspira a destacar las virtudes regias, firmes y excelentes en cualquier momento, y afirmar el papel fundamental de la Providencia, siempre protectora.

Entre los textos vernáculos en torno al atentado sorprende el Tratado de la herida del rey de Alfonso Ortiz, publicado junto con otros cuatro opúsculos más en Sevilla $(1493)^{58}$. Con ese texto, que encabeza el volumen, Ortiz se presenta ante los reyes como un hombre de letras y de Iglesia totalmente rendido a su servicio, deseoso de serles de ayuda, tal y como expone al final de su obra, donde suplica a sus majestades «con humil acatamiento [...] que reciban mi deseo de su servicio más que esta obra» (fol. 8v, col. A). Su tratado es un ejemplo más de lo que Cátedra ha bautizado como literatura funcionarial ${ }^{59}$, característica de ese momento y de la que son buena muestra las cartas y crónicas antes citadas. Con este tratado, Ortiz se postula como un leal consejero que teoriza sobre las consecuencias y significados más profundos del atentado, en realidad un regalo de Dios que les permitirá avanzar hacia un mejor gobierno del reino y de sus personas. Por ello, les invita a la reflexión, la penitencia y la humildad. Se trata, en definitiva, de un ejemplo cabal de literatura consolatoria ${ }^{60}$ que, según avanza, se convierte en un sucinto y perfecto speculum christiani principis ${ }^{61}$. Desde luego,

58 Alfonso Ortiz, Los tratados del doctor Alonso Ortiz: Tratado de la herida del Rey; Tratado consolatorio a la Princesa de Portugal; Oratio ad Ferdinandum et Elisabeth, Hispaniarum regem et reginam, de triumpho Granatensi; Cartas que enviaron a los reyes el cabildo de la Iglesia y la Ciudad de Toledo en defensa de la preeminencia de esta sobre la ciudad de Granada; Tratado contra los errores del protonotario fuan de Lucena, Sevilla, 1493. Para esta obra y el resto de los escritos de Ortiz en castellano, vid. Fernando GÓMEZ REDONDO, Historia de la prosa... [ver n. 38], pp. 839-872 (el Tratado de la herida del rey, pp. 849854). Ángel SESMA, Los idus... [ver n. 7], ofrece una mera transcripción del texto, sin notas y sin adoptar una puntuación moderna, lo que puede dificultar un tanto su lectura. Yo me he servido del Inc. 1905 de la BNE. En mis citas, acentúo y puntúo el texto de acuerdo con las normas actuales. Este texto de Ortiz guarda ciertos paralelismos con la «Exortación a los Reyes nuestros señores sobre el caso acaescido» de Diego Muros III (Valladolid, 1493), cuyo análisis quedará para otra ocasión. Ver José GARCÍA ORO, Diego Muros III y la cultura gallega del siglo XV, Vigo, 1976, pp. 163 y ss., y Régula rohland de langbehn, La Exortación a los Reyes, nuestros señores, sobre el caso acaescido de Diego de Muros, un De Regimine Principum de finales del siglo XV, en Atalaya, 6 (1995), pp. 81-115.

59 Pedro CÁTEDRA, La literatura funcionarial... [ver n. 26].

60 Sobre el género de la consolatoria en la España del siglo XV, vid. Pedro M. CÁTEDRA, Creación y lectura. Sobre el género consolatorio en el siglo XV: La Epistola de consolaçión enbiada al reverendo se or Prothonotario con su respuesta (c. 1460), Medieval Hispanic Studies in Honor of Charles F. Fraker, Madison, Wisc., 1995, pp. 35-61; Modos de consolar por carta, en José Manuel Lucía (ed.), Actas del VI Congreso Internacional de la Asociación Hispánica de Literatura Medieval (Universidad de Alcalá, septiembre de 1995), t. 1, Alcalá de Henares, 1997, pp. 469-487.

61 No fue esta la única ocasión en que Ortiz da cuenta de sus opiniones políticas a los Reyes Católicos, como ha demostrado Núria SILLERAS-FERNÁNDEZ, The Queen, the Prince and the Ideologue: Alonso Ortiz's Notions of Queenship at the Court of the Catholic Kings (La reina, el principe y el ideólogo: Alonso Ortiz y sus nociones de reginalidad en la corte de los Reyes Católicos), en Anuario de Estudios Medievales 46, 1 (2016), pp. 393-415. 
el título de «Tratado» con que bautiza su escrito invita a pensar, por una parte, en el género del sermón u homilía ${ }^{62}$, que se percibe en el tono admonitorio adoptado por Ortiz para consolar a los reyes por su desgracia; por otra parte, en el escrito doctrinal, ya que se dictan consejos prácticos para la salud moral de los monarcas y sus reinos.

Ortiz es consciente de la novedad de su arte y, como declara en el opúsculo consolatorio que sigue a este, pretende medirse en vernáculo con los extranjeros que, sirviéndose del latín, se habían apropiado de este género. La intención del autor es clara: mostrar sus habilidades retóricas, desarrollando un estilo elevado, y hacer una lectura positiva del suceso con el que Dios ha querido «despertar» los corazones de los soberanos y poner a prueba su prudencia. El texto se articula en varios parágrafos o capítulos (6 en total), en los que se observan las divisiones propias de un sermón pasado por la horma de la oratio clásica: no hay un versículo bíblico o tema sobre el que articular una glosa, pero sí se percibe clara la intención admonitoria y penitencial ${ }^{63}$. Aquí, los ejemplos bíblicos se dan la mano con referencias al Mundo Antiguo; la voz del escritor se mezcla con la del rey Fernando, que dicta consejos a su hijo e hija. Estamos, pues, ante un texto híbrido, un escrito que participa por igual del sermón, la epístola doctrinal y la oratio.

Tras unas breves palabras de presentación, con las que se enuncian los temas principales, se invita a dar gracias a la Virgen María por haber actuado como intercesora y haber salvado al rey ${ }^{64}$. Tras este introito, prosigue la narratio del suceso, dividida en dos apartados («Narración breve» $\mathrm{y}$ «Prosigue»), donde se ofrecen una sucinta descripción de los hechos, ocultando deliberadamente el nombre del criminal, y una ponderación exacta de la clemencia del rey, manifestación clara de la piedad religiosa de quien se preocupa más de la salud del alma que la del cuerpo. Ortiz se detiene y exagera los signos de turbación mostrados por los ciudadanos y, al punto, su plática se desvía y se dirige en exclusiva a la reina,

62 Aunque en su estudio Francisco Javier TOVAR PAZ, 'Tractatus, sermones atque homiliae': el cultivo del género literario del discurso homilético en la Hispania tardoantigua y visigoda, Cáceres, 1994, se refiere a una época distinta, sus consideraciones son válidas para este texto.

63 Sobre los sermones medievales en castellano y sus componentes resulta muy útil el trabajo de Pedro M. CÁTEDRA, Sermón, sociedad y literatura en la Edad Media. San Vicente Ferrer en Castilla (1411-1412), Salamanca, 1994, en especial pp. 171-222.

64 Aunque aquí no se trata de un Ave María ni de una oración al uso, vale recordar que Francesc Eiximenis preceptuaba en su ars predicandi que, una vez acotado el thema, se hiciese una oración a la Virgen. Esta práctica fue adoptada, entre otros, por predicadores tan exitosos como Vicente Ferrer (vid. Pedro CÁTEDRA, Sermón, sociedad... [ver n. 54], p. 177, n. 10). 
cuya actuación, signo de una fortaleza casi viril, es elogiada: «aunque fuyeron tus gozos, quedaron firmes tus consejos y venciste tu femíneo vigor dando esfuerço a los más animosos» (fol. 2v, col. B). Todo en ella fue buen hacer, pues confortó a los cortesanos, cortó cualquier tipo de rumor y aplicó todas las medidas a su alcance para atajar cualquier intento de levantamiento o alboroto. De la narración de estos primeros momentos, se extraen unas primeras enseñanzas, que Ortiz regala a la reina, como si de un sermón se tratase, para que esta persevere en el cultivo de la virtud y en la fortaleza:

De los justos solos y amigos de Dios es perseverar en una firmeza entre las ondas salobres y dulces de este piélago de la vida, porque saben cierto que de los trabajos se sembran los gozos eternos, y de los vanos deleytes nascen los amargos dolores a los indiscretos (fol. 3, col. B).

Tras estas consideraciones, Ortiz elogia la modestia, la constancia del rey y, una vez más, su clemencia («Tornemos, pues, a la discreta modestia y viril constancia tuya, rey muy excelente, y consideremos con qué clemencia defendiste la vida del violador de tu magestad» [fol. $3 \mathrm{v}$, col. A]), antes de dar paso el siguiente capítulo: «Capítulo de la providencia del rey», un auténtico ejercicio de estilo, en que Ortiz imagina las supuestas palabras del rey a su hijo Juan y a su hija la princesa Isabel ${ }^{65}$ nada más ocurrir el atentado y ante la posibilidad de una muerte cercana. Esas palabras se reproducen en estilo directo y, como cabe suponer, abundan las recetas morales, que inciden en la necesidad de llevar una vida recta marcada por el temor a Dios, porque la muerte puede acechar a cualquiera en cualquier momento. Las palabras del rey Fernando constituyen, en definitiva, un auténtico sermón, plagado de lugares comunes, que se refuerza con citas bíblicas y alguna referencia a san Isidoro y Séneca. El estilo es sentencioso, con frases cortas, que le dan el tono característico de la literatura moral. A su hijo, el rey le dedica un breve tratado del buen gobierno, con el consejo de que las virtudes cardinales se conviertan en su la única guía, guardando siempre el temor a Dios: «La justicia sea tu ceptro, la prudencia tu consejo, tus armas la fortaleza, tu regimiento la templanza» (fol. 4, col. A). A su hija, en cambio, le dirige palabras de consuelo para que enjugue sus lágrimas y acepte el dolor de la pérdida con resignación (la joven princesa penaba también por la muerte repentina de su marido,

65 Aunque no se dice el nombre de la princesa, cabe sospechar que se trata de doña Isabel, viuda entonces del príncipe don Alfonso de Portugal, a la que va dedicado el segundo tratado de este libro publicado en Sevilla por Ortiz, Tratado consolatorio a la Princesa de Portugal [ver n. 54]. 
el príncipe don Alfonso de Portugal, en julio de 1491, según se desprende de las palabras de su progenitor).

El retrato del rey que sale de aquí no podía ser más positivo: Fernando es un rey justo, temeroso de Dios, un auténtico rey prudente (de ahí el título del capítulo) que, ante la presencia de la muerte, rodeado por los suyos, dicta sus últimos consejos $^{66}$. Al final del capítulo, Ortiz toma de nuevo la palabra para adoptar el papel de consejero y recordar al rey que siempre ha de tener en mente dos cosas, que constituyen la enseñanza esencial contenida en el tratado:

La una, nuestra humana flaqueza, con cuya memoria nos enfrena el temor de Dios en las glorias d'este siglo; la segunda, la guarda de su consciencia en la justa gobernación de sus reynos, de las quales por orden se tratará (fol. 4, col. B).

Estos dos temas, según se anuncia, proporcionan la materia para los dos capítulos siguientes. Sin embargo, no esperemos una simple narración, pues la finalidad del texto no solo es didáctica (docere) sino que pretende conmover (movere), por lo que la consideración de la fragilidad humana se hace bajo el modo de una «Exclamación». Como indica el título de este nuevo apartado, todo se vuelven exclamaciones, lamentos y apóstrofes contra las miserias de la vida humana y loas a favor de la razón, que es el único gobernalle para una vida feliz. Resuenan aquí, una vez más, los temas tradicionales de la vanidad, los caprichos de la Fortuna, sus veleidades y peligros, las adversidades como instrumento de aprendizaje. No faltan ejemplos tomados de la Biblia, como Nabucodonosor, al que las desgracias hicieron mejor, o Abraham, y otros del mundo clásico, como los argonautas, que aprendieron en medio de las dificultades; Hércules, cuyos trabajos solo le dieron una gloria que perdió por su naturaleza libidinosa; Octaviano, gran amante de la paz, o Aníbal, ejemplo de cómo el ocio todo lo destruye.

Ortiz se dirige a los soberanos y les propone una manera de actuar atenta a sus consejos; así, asegurado el apoyo divino, podrán proseguir con sus tareas, entre las que se enuncian la reforma de la iglesia, el problema de los herejes o las negociaciones con Francia sobre los condados. No faltan las llamadas al irenismo,

66 Esta imagen del rey moribundo que, tranquilo, pasa el testigo a su heredero evoca la imagen de la buena muerte de la que tanto hablaron los manuales; así, en el momento mismo del tránsito, ya en paz el alma, el noble o rey pueden dictar aún sabios consejos. Así se presenta Rodrigo Manrique y así lo hacen también numerosos santos en el momento mismo de su martirio. Un ejemplo perfecto de este patrón lo tenemos en el relato de la muerte de Fernando III según la presenta la Crónica general (vid. Jenaro COSTAS, Fernando III a través de las crónicas medievales, Zamora, 2001, p. 38). 
pues la concordia entre los dos grandes reinos, gracias precisamente a la voluntad divina, permitirá «magnificar y reformar la religión christiana, la qual, impressa en los coraçones reales vuestros y d'aquel tan excelentíssimo rey, prosperará en aumento muy bienaventurado» (fol. 5v, col. A).

El tratado concluye con un último capítulo en el que, según el plan propuesto, se aconseja a los soberanos que se esfuercen en la justa gobernación del reino, que constituye en definitiva la enseñanza esencial derivada del atentado: « ¿Para qué despertó Dios los coraçones vuestros con su visitación?». El punto de partida, como en cualquier sermón, es un salmo (Sal. 2, 10-12): «Entended agora, o reyes, mi enseñanza los que judgades la tierra. // Servid al señor con tremor, // ensalçadle con tremor, tomad esta disciplina porque con su saña no perezca vuestro poder de las justas carreras y quando se encendiere su yra. Bienaventurados los que confían en él». A partir de aquí, Ortiz regala a los monarcas su personal speculum principis, en el que no faltan referencias de pasada a la República de Platón, al de De regno de santo Tomás y, sobre todo, a san Agustín, De civitate Dei, 5, 24, que glosa y resume. Dicho de otra forma, el atentado ha cumplido su cometido al poner sobre aviso a los reyes que deberán perseverar en el cultivo de las virtudes (pietas o temor de Dios, humildad, justicia, clemencia o liberalidad) en pro de sus súbditos y su reino. Si hacen todo esto, tal y como aquí se les recuerda, ganarán el apoyo divino además de la paz y la concordia en sus dominios. Solo queda despedir el tratado, ofreciéndose humildemente a servirles siempre, una promesa que cumplió a juzgar por el resto de sus obras.

Todos estos textos muestran la rapidez e inteligencia con que actuaron los reyes ante un suceso tan grave. Casi de inmediato, sus consejeros y colaboradores más cercanos redactaron y dieron a conocer la versión oficial de los hechos. En aquellos momentos de tribulación, se hizo hincapié, por un lado, en la necesidad de mostrarse prudentes, humildes y de dar gracias a la Virgen y a Dios por haber evitado un mal mayor (con lo que se reforzaba su imagen de reyes piadosos y se les inducía, a ellos y a sus súbditos, a realizar algún tipo de examen de conciencia y penitencia); por otro, se aprovechó la circunstancia para lanzar un mensaje político claro: que nada había cambiado, pues los soberanos proseguían con su idea de continuar la guerra por el norte de África y estaban preparados para hacer valer sus derechos ante Francia y en Italia. Dichos mensajes viajaron dentro y fuera de nuestras fronteras con la celeridad acostumbrada. Con esa manera de proceder, aquellos escritores y consejeros convirtieron una posible tragedia en un acto más de afirmación de las virtudes de los reyes, que fueron presentados de nuevo como ejemplos cabales de prudencia, clemencia y justicia. 


\section{LA EPÍSTOLA REGOGIDA EN EL MS. 7076 DE BNE}

El ms. 7076 de BNE contiene una versión castellana de la Ética a Nicómaco de Aristóteles ${ }^{67}$; en realidad, se trata del Compendio de las Éticas atribuido a Nuño de Guzmán, un texto que gozó de enorme éxito y del que existen también versiones en aragonés y catalán ${ }^{68}$. El manuscrito está escrito en letra gótica aragonesa $c a$. 1490-1500, fecha probable de su composición.

En los folios finales de ese manuscrito (fols. 70r-v), alguien copió una carta, en una típica letra cursiva del XV, dirigida a la reina Isabel; en ella, para apoyar una petición de perdón, se hace una alusión expresa al atentado de Barcelona. Es posible que la carta se escribiese poco después de ese suceso, que aparece citado como la última de una serie de ocasiones en que Dios había salvado la vida a los monarcas tras ponerles a prueba. Por ese motivo, como los soberanos cuentan con el apoyo de la Providencia y la naturaleza les ha dotado de buen juicio, se les pide que, sin hacer caso de los malos consejeros, actúen en el caso que aquí se les presenta (del que nada sabemos) como siempre han hecho, con justicia y clemencia. La carta comienza sin ningún preámbulo con una cita de Eccli. 2, 5 sobre el poder del fuego para depurar el oro, una metáfora que se glosa de manera conveniente, para incidir en la idea de que las dificultades a las que los reyes se han visto sometidos no han hecho sino acrecentar sus virtudes.

Tras esa breve explicación, viene la petitio, en realidad tres súplicas; de ellas, la más importante es la última, en que se apela a la misericordia de los reyes para que no se aplique al autor de la misiva la pena que se le ha impuesto. Concluida la carta con el reconocimiento de que tal vez esta petición peque de osada, el autor copia unas cuantas sentencias que, según dice, proceden del De clementia de Séneca. Sin embargo, esa afirmación no es del todo cierta, pues la primera cita proviene de las Controversiae de Séneca el Viejo, padre del filósofo. Llegados a

67 Agradezco a la profra. María Díez Yánez su amabilidad por facilitarme toda la información sobre este manuscrito (vid. María DíEZ YÁNEZ, Comentarios y paráfrasis a la Ética a Nicómaco, a propósito de los MSS BNE: 6710, 7076 y 1204, en Antonia MARTÍNEZ PÉREZ-Ana Luisa BAQUERO EsCUDERo [coord.], Estudios de Literatura Medieval. 25 años de la Asociación Hispánica de Literatura Medieval, Murcia, 2012, pp. 317-330).

68 La versión catalana ha sido estudiada y editada por Cuenca i Alemenar, quien ofrece también un detallado estudio del manuscrito madrileño y de los demás testimonios que transmiten este compendio hispánico de la Ética (vid. Salvador CUENCA I ALEMENAR, L'Ėtica nicomaquea d'Aristótil en un compendi català del seglo XV, en Anuari de la Societat Catalana de Filosofía, 22 [2012], pp. 7-119. La descripción del manuscrito castellano y la información relativa a la carta dirigida a la reina Isabel, en pp. 19 y 33$)$. 
este punto, es imposible saber si esas frases se copiaron aquí como parte integral de la misiva o si, por el contrario, son unos apuntes independientes. Aunque es fácil percibir la relación de estas máximas con el cuerpo de la carta (todas celebran la clemencia de que hicieron gala algunos próceres de la Antigüedad), nada se puede concluir al respecto.

Para la edición del texto, realizo una transcripción semipaleográfica con la restitución de las abreviaturas de época sin indicación expresa. He modernizado la acentuación, la puntuación y el uso de las mayúsculas. He regularizado el uso de la 'u' y la 'v', según tengan valor vocálico o consonántico, pero he mantenido la 'u' superflua en grafías como «fueguo», «guovernación», etc. He actuado de igual modo con relación al uso de la 'i', 'j' e 'y'.

Muy alta e muy poderosa christianíssima reina nuestra señora:

Lo mesmo que aze el fueguo al oro quando lo çendra y la lima al fierro quando lo brunye, aze la tribulación al virtuoso quando lo angustia, que le apura lo malo y le afina lo bueno; así creo vuestras reales majestades están aora con la fuerza deste fueguo con muy cendradas y afinadas voluntades pora la maternal justicia, natural clemencia, cuidosa deligincia $[s i c]$ y para todas las otras cosas que a vuestra real guovernación conviniere.

Tres cosas suplico a vuestras altezas: la primera que la buena disposición que salle cendrada y apurada deste fueguo en tal estabege ${ }^{69}$ se pongua que no sia menester cendrarse otra vez. La segunda que en este juicio de Dios, donde ay grande abisimo, no reciba glosas agenas sino sola la de vuestras reales discristiones [sic], pues en sí son tan excellentes que de sus personas y regnos saben más que ninguno. La terzera que, pues tanto juntas vivieron en este nuestro espanto la justicia y la misericordia de Dios, la justicia en quitarnos la vida; la misericordia en nos la dexar, ansí juntamente se considere quánto deve ser temido quien ansí nos la puede quitar y quánto deve ser amado quien así nos la torna y, para que vuestras reales majestades muchas vezes mucho lo puedan agradecer, tenguan siempre en su real memoria quántas vezes la bondad de Dios le a echo merzed de la vida del rey nuestro senyor el qual bive sobre la común costumbre delos ombres: en Malegua una, en Baça otra, en Sivilla otra, en Gualiçia otra; aguora en Barcelona, esta es tanto clara que los cieguos la veen.

Supliquo a vuestra alteza mande perdonar a mi atrevimiento que su causa lo aze digno de perdón y aún de merzed, y suplico a nuestro Señor guarde a vuestras altezas.

69 Debo a mi compañero el prof. Pedro Sánchez Prieto el esclarecimiento de este término. La palabra puede ser un aragonesismo o catalanismo y equivale, según Corominas, $D C H C$ a «escabel». Esta palabra en aragonés, y posiblemente procedente de Gascuña, aparece como «escabech»y, en castellano, como «escamel» («instrumento de espaderos en el cual se tiende y sienta la espada para labrarla»). Se recoge también la forma «scabex» en un inventario de 1499. 
Doctrina del libro de Senequa llamado Clemencia

César, los que delante osan hablar no saben la tu grandeza y los que delante de ti non osan ablar no conocen la tu bondad y gran humanidat ${ }^{70}$.

Otra doctrina de Senequa

Car en los grandes barones estonzes parecen e son famosas las virtudes quando usan de su poderío para guardar la salut de los otros, ca ser ombre poderoso para azer mal poderío de pestilencia ${ }^{71}$.

Otra doctrina

Propia cosa es del gran corazón ser pacible e manso e soseguado e menospreciar altamente las injurias y ofensas que le fazen, car obra de muger es enloquezerse con sanya ${ }^{72}$.

Otra doctrina de Senequa

Començó la muger de Octaviano emperador e dixo: «Octaviano, ¿quieres agora recebir un consejo de muger? Fes lo que los físiquos azen, los quales quando ven que las medecinas usadas non aprovechan pruevan las contrarias y así deves tú azer con los que mal te $[\ldots] \gg^{73}$. Este consejo próspero ${ }^{74}$, Octaviana.

70 En este caso, frente a lo que se dice, la cita no procede del De clementia. Se trata en realidad de una frase atribuida a Vario Gémino y recogida por el padre del filósofo, Séneca el Viejo (Sen. Con$t r .6,8)$ : «Caesar, qui apud te audent dicere magnitudinem tuam ignorant, qui non audent, humanitatem». Esta frase se hizo muy popular y la encontramos citada por autores tan distantes en el tiempo como Pedro Abelardo y Petrarca.

71 Sen. Clem. 1, 3, 3: «Nullum tamen clementia ex omnibus magis quam regem aut principem decet. Ita enim magnae vires decori gloriaeque sunt, si illis salutaris potentia est; nam pestifera vis est valere ad nocendum».

72 Sen. Clem. 1, 4, 5: «magni autem animi proprium est placidum esse tranquillumque et iniurias atque offensiones superne despicere. Muliebre est furere in ira».

73 A partir de aquí no se puede leer bien el texto porque ha sido mutilado por la guillotina.

74 Esta palabra es mera conjetura porque la guillotina no permite leerla bien. 